ARTIKKELI

\title{
VoITONPÄIVÄNJUHLA SORTAVALASSA
}

\author{
Juhlinnan ja muistin politiikkaa rajakaupungissa
}

Olga Davydova-Minguet

Vuonna 2014 itsenäisyyspäivän juhlassa Joensuussa pidetyssä puheessa Itä-Suomen yliopiston historian professori Jukka Korpela luonnehti kansallista historiaa, kansakunnan tarinaa "saduksi, jota kansakunnat tarvitsevat". Hän esitti myös, että "kansakunnan satu" ei voi pysyä muuttumattomana sukupolvelta toiselle, vaan sen on pakko muuttua, koska itse yhteiskunnat ja niiden jäsenten kokemukset muuttuvat. Merkillepantavaa oli paikka ja tilaisuus, jossa näitä ajatuksia esitettiin. Itsenäisyyspäivän juhlinta välittää vakiintunutta suomalaisen kansakunnan kertomusta (ks. esim. Raudaskoski 2015; Paasi 2015), ja sen kritiikki itse juhlan ytimessä kuulosti yllättävältä ja rohkealta.

Kansallispäivät ovat "kansakunnan satujen" kehittämisen, välittymisen ja uusiutumisen kannalta keskeisiä tapahtumia. Kuitenkin jo niiden valinta monien mahdollisten kansakunnan "päätapahtumaan" viittaavien päivien joukosta osoittaa niiden arbitraarisuuden. (Nyyssönen 2012.) Kansallispäivän valinnassa määritellään sopiva historiantulkinta ("satu"), siihen viittaamisen tavat (esimerkiksi karnevaali tai vakava juhla, sotilasparaati tai mielenosoitus), kansalliset sankarit, toimijat, yleisöt - ja myös merkitään koko kalenterivuosi erinäisillä kansakuntaan viittaavilla ja kansallispäivään yhteydessä olevilla muistopäivillä. Kansallispäivät voi nähdä Pierre Noran (1989) määritelmän mukaisina muistin paikkoina (lieux de mémoire), joita kansakunnat viljelevät kollektiivisen muistinsa (ja itsensä) ylläpitämiseksi.

Kansakuntien yhtenäiset ja yhtenäistävät kertomukset ovat olleet kriisissä jo pitkään. Nora (2002) on kuvannut kansakunnan universaalien historioiden kyseenalaistuneen Ranskassa ja yleisesti ottaen Länsi-Euroopassa 1970-luvulla vähemmistöjen tunnetuksi ja tunnustetuksi tulemisen myötä: kansakuntaa yleistävän historian tilalle on tullut pirstaleinen eri ryhmien "muisti". Myös neuvostojärjestelmän hajoamista edeltänyt ja sitä seurannut historian uudelleenarvioinnin vaihe on johtanut siihen, että suuret, ennen kaikkea toiseen maailmansotaan liittyvät ja uusien kansakuntien roolia esittävät kertomukset ovat joutuneet ankaran kritiikin kohteeksi, ja kylmän sodan aikainen "historiakertomusten tasapaino" on muuttunut. 
Voikin sanoa, että eurooppalainen keskustelu koskien toista maailmansotaa on kehittynyt synnyttäen uusia jakoja laajoihin muistiyhteisöihin. (Miller \& Lipman 2012; Mužnieks 2008; Zhurzhenko 2011.) Länsi-Euroopassa sotamuistoa rakenteistava keskustelu on keskittynyt holokaustiin, ja pohtinut sitä mahdollistaneita kehityksiä sekä tapoja muistaa sotaa ja sen kauheuksia ihmisoikeuksien näkökulmasta (Assmann 2014). Entiset sosialistiset keskisen Itä-Euroopan maat ovat kehittäneet historianarratiivia, joka esittää niiden kansakunnat totalitaristisen neuvostojärjestelmän miehityksen uhreina. Tämä mielikuva kehittyi dialogissa EU:n ja Venäjän kanssa, joka asteittain otti itselleen roolin Neuvostoliiton perijänä ja loppujen lopuksi ajautui pysyvään vastakkainasetteluun niin uusien kuin vanhojenkin EU-maiden kanssa. (Miller 2012.) Ukrainan kansannousu, Krimin valloitus ja sodan syttyminen Itä-Ukrainaan ovat entisestään kärjistäneet kansainvälistä "historiasotaa" ja sotaan liittyvien mielikuvien ideologista käyttöä (Etkind 2015, 256). Vaikuttaa siltä, että toisen maailmansodan tulkinnat ovat ideologisoituneet ja tulleet käyttökelpoiseksi ainekseksi "kansallisten muistien" uudelleenjärjestäytymisessä.

Tässä artikkelissa tarkastelen, kuinka kansallista muistia luodaan kansallispäivän juhlassa, voiton päivän juhlinnassa Sortavalassa, joka sijaitsee 60 kilometrin päässä Suomen rajalta ja kuuluu hallinnollisesti Karjalan Tasavaltaan ${ }^{1}$. Kansallisten juhlien, muun muassa voitonpäivän merkitystä analysoidaan tavallisesti kansallisessa kontekstissa, ja tutkijan katse ja aineisto keskittyvät vahvasti juhlan kannalta keskeisiin paikkoihin kuten pääkaupunkeihin (esim. Andreev \& Bordjugov 2005; Dubin 2004 ja 2005; Tumarkin 2003). Muita juhlan viettopaikkoja ja niissä syntyviä juhlan merkityksiä on tutkittu lähinnä entisissä neuvostotasavalloissa, joiden nykyinen historianarratiivi eroaa jyrkästi nykyvenäläisestä. Silloin kiinnostuksen kohteena on venäjänkielisen väestön identiteetti ja valtaväestöstä eriävät sodan tulkinnat. (Ks. Ločmele \& al. 2011; Onken 2007a; 2007b; Smith 2008.) Sortavala voi tarjota kiinnostavia perspektiivejä kansallisen juhlan ja voitonpäivän pohdintaan: se on Venäjän syrjäinen kaupunki ja rajakaupunki, jossa yhteydet naapurimaahan ovat vilkkaita ja arkisia, sekä kaupunki, jonka "kansallinen omistus" on muuttunut juuri juhlassa muistettavan sodan tuloksena. Sortavalan seudun historia poikkeaa suuren isänmaallisen sodan narratiivista: tämä alue oli valloitettu isänmaallista sotaa edeltäneessä sodassa eivätkä kaupungin nykyasukkaiden esi-isät puolustaneet täällä "omaa maata", mihin termi "isänmaallinen sota" viittaa. Tarkastelussani kiinnitän huomiota siihen, kuinka juhlaan osallistuvat paikalliset toimijat luovat juhlaan omia merkityksiä. Minua kiinnostaa, kuinka neuvostoajoilta peräisin oleva, nykyoloihin sopeutettu rituaali toimii kaupungissa, joka on kaukana kansallisista keskuksista mutta lähellä rajaa. Kuvaan rituaalin paikkaa, kulkua, erittelen sen toimijoita ja heidän toimissaan ja puheissaan esitettyjä käsityksiä sodasta ja voitosta sekä nykykansakunnasta.

Olen kiinnostunut Sortavalasta osana Venäjän ja Suomen välistä rajaseutua. Yleisesti ottaen minua kiinnostavat muistiin ja historian tulkintoihin liittyvät prosessit, joissa tehdään eroa tai luodaan yhteyttä naapurimaahan. Näkökulmani

1 Karjalan tasavalta sai nykyisen nimensä v. 1990, sitä ennen se oli Karjalan autonominen sosialistinen neuvostototasavalta (1956-1990), Karjalan sosialistinen neuvostotasavalta (1940-1956), Karjalan autonominen sosialistinen neuvostotasavalta (1923-1940) ja Karjalan työkommuuni (1920-1923). 
on lähtökohtaisesti transnationaali, ylirajainen. Venäjän ja EU:n välisten suhteiden Krimin miehityksestä johtuneeseen kärjistymiseen asti Karjalan tasavallan ja Suomen rajaseutujen asukkaiden väliset suhteet kehittyivät noususuuntaisesti, ja jatkuvasti lisääntynyt matkailu ${ }^{2}$, maahanmuutto Suomeen ${ }^{3}$ sekä taloudellinen ja hallinnollinen yhteistyö ovat tehneet raja-alueista ylirajaiset (ks. Pöllänen 2013; Davydova \& Pöllänen 2010). Näissä arkisissa kontakteissa historian tulkinnat ovat läsnä: maisemaan sijoittuvina muistomerkkeinä, museonäyttelyinä, kansallisina lippuina, juhlina sekä inmisten käsityksinä ja neuvotteluina "meistä" ja "muista"

\section{NYKY-SORTAVALA}

Sortavalaan liittyy monia historiakertomuksia. Suomessa se yhdistetään miltei automaattisesti menetettyyn Karjalaan. Raja- ja Laatokan Karjalan menetys ja evakkoon joutuneiden inmisten kokemukset muodostavat nykysuomalaisuuden eräänlaisen kärsimystarinan, ja tämä kertomus on erittäin hyvin artikuloitu muistelmakirjallisuudessa, elokuva- ja muissa taiteissa sekä historiankirjoituksessa. Menetettyjen alueiden asukkaiden monenlaiset yhdistykset jatkavat toimintaansa edelleenkin, vaikka alueiden menetyksestä on kulunut jo 70 vuotta. Rajojen avauduttua Karjalan entiset suomalaiset asukkaat, heidän jälkeläisensä ja yhdistyksensä aloittivat valtavan alueiden "palautustyön": entisillä kotiseuduilla käydään, sinne pystytetään muistomerkkejä, ja niitä koskevat muistot ovat saaneet uutta voimaa ja uusia tulkintoja (Fingerroos 2007; 2010; Fingerroos \& Loipponen 2007).

Tällä hetkellä kaupungin asukasluku on 23 000, ja koko Sortavalan piirin 32000 asukasta. Sortavalan ja ylipäänsä koko Suomelta valloitetun alueen nykyinen väestö on muodostunut monen muuttovirran tuloksena. Ensimmäisiä asukkaita tuli alueelle heti talvisodan päätyttyä, sittemmin heidät evakuoitiin ja tuotiin takaisin jo jatkosodan jälkeen. Ensimmäiset asukkaat tulivat Laatokan seudulle 1940-luvulla Neuvostoliiton eri kolkista: etupäässä Valkovenäjältä ja Ukrainasta, Mordvan, Tshuvassian, Tatarian autonomisista tasavalloista sekä Vologdan, Kalininin, Kirovin, Penzan, Rjazanin, Smolenskin ja Tulan alueilta. Ihmisiä muutti perhekuntina, kokonaisina kolhooseina ja yksitellen. Entisessä Suomen Karjalassa heitä odottivat suhteellisen hyvin säilyneet rakennukset ja maisemat ilman paikallista väestöä. Tulokkaiden tehtävänä oli tehdä alueista "omia", niin ottamalla haltuun säilyneet rakennukset ja opettelemalla käyttämään maatalousmaita kuin tekemällä nämä alueet henkisesti omiksi luomalla esimerkiksi niihin liittyviä kertomuksia, selityksiä ja uskomuksia. (Ks. Hakamies 2005; Hakkarainen 2005; Krasnolutski 2012, 23442; Laine 2001; Laine 2005; Melnikova 2005a ja 2005b; Melnikova 2009.)

Sodanjälkeisenä aikana Sortavala on pikkuhiljaa muotoutunut syrjäiseksi Neuvosto-Karjalan kaupungiksi, jolle on kehittynyt omat elinkeinot ja kulttuurielämä. Kaupunki oli myös pitkään vahvasti militarisoitu ja suljettu ulkopuolisilta: jopa

2 Niirala-Värtsilän rajanylityspaikka on Suomen ja Venäjän välisen rajan neljänneksi vilkkain. Vuonna 2014 siinä kirjattiin 1608847 rajanylitystä. Verrattuna edelliseen vuoteen ne olivat vähentyneet t 8,8 \% johtuen muuttuneesta kansainvälisestä ilmapiiristä ja ruplan arvon romahtamisesta (Rajavartiolaitos 2015).

3 Vuonna 2014 Pohjois-Karjalassa asui yli 2800 venäjänkielistä henkilöä, joista yli 1500 oli Venäjän kansalaisia (Tilastokeskus 2015). 
Neuvosto-Karjalan asukkaat tarvitsivat erikoisluvan päästäkseen raja-alueelle. Sortavala pysyi suljettuna vuoteen 1990 samoin kuin koko Pohjois-Laatokan seutu. (Izotov 2001.) Värtsilä-Niiralan rajanylityspaikan avauduttua entisille Suomen alueille suuntautui ennennäkemätön virta niiden entisiä asukkaita, ja entisen suljetun kaupungin asukkaat tulivat silmänräpäyksessä kosketukseen sen historian kanssa, jota ei neuvostoaikana sallittu eikä tunnettu. Voikin sanoa, että he olivat ensimmäisiä Karjalan kansainvälistyjiä. Kanssakäyminen Suomen ja suomalaisten kanssa on kuluneen yli kahdenkymmenen vuoden aikana muuttunut kaksisuuntaiseksi: Venäjän puoleisten rajaseutujen asukkaat ovat "ottaneet omakseen" Suomen rajaseudut. Suomessa käydään usein lomailemassa, ostoksilla ja työssä. Suomeen suuntautuvan maahanmuuton takia monilla on sukulaisia ja ystäviä rajan toisella puolen.

Suuri osa Sortavalan keskustan rakennuskannasta on peräisin ajalta ennen toista maailmansotaa. Rakennuksia ei ole juurikaan entisöity, minkä vuoksi kaupunki näyttää ränsistyneeltä. Sen historiallisten rakennusten ja arkkitehtonisten kokonaisuuksien kunto onkin herättänyt huolta paikallisten kulttuuriperintöaktivistien keskuudessa (haastattelu 7). Suomessa kaupunkiin suhtaudutaan eräänlaisena suomalaisuuden ja suomalaisen 1800-luvun ja 1900-luvun alun arkkitehtuurin muistomerkkinä. Suomessa samantyyppisten puurakennuksista koostuvien kaupunkien keskustat eivät ole säilyneet näin kokonaisina, vaan niitä on vuosien saatossa muokattu ja nykyaikaistettu. (Björn 2001.) Suomalaisessa kävijässä Sortavala herättääkin usein hämmentäviä tunteita; se on samalla kultainen ja kurja kaupunki, jota katsotaan väistämättä menetyksen ja surun kautta (Ahponen 2011; ks. myös Fingerroos \& Loipponen 2007; Fingerroos 2007; Loipponen 2007). Venäläiselle matkailijalle kaupungilla on puolestaan selvästi "länsimainen" leima johtuen kaupungin keskustan arkkitehtuurista ja sen historiasta sekä Suomen läheisyydestä. (Izotov 2008.)

Sortavalan keskustakuvaa hallitsee suomalainen kansallisromanttinen ja funkkistyylinen arkkitehtuuri. Sen kaavaa ei ole muutettu sitten toisen maailmansodan. Keskustassa on säilynyt myös joitain suomalaisia muistopatsaita sotaa edeltävältä ajalta kuten vuonna 1935 pystytetty Petri Shemeikan patsas. Sodassa raunioituneiden talojen paikalle on rakennettu tyypillisiä 1960-1970-lukujen kerrostaloja, jotka selvästi eroavat suomenaikaisista. Keskustaan on myös pystytetty joitakin muistopatsaita, kuten neuvostosotilaiden sankarihaudalle 1950-luvulla pystytetty surevaa sotilasta ja lasta sylissä pitävää äitiä esittävä patsas sekä Vakkosalmen toiselle rannalle, koulun viereen neuvostosotilasta esittävä patsas. Myös suomalaisten sotilaiden muistoksi on pystytetty kaupungin keskustaan suomalaisten voimin muistoristi vuonna 1996.

Olen asunut puolet elämästäni Neuvosto-Karjalassa ja puolet Suomessa. Kävin Sortavalassa ensimmäisiä kertoja lapsena neuvostoaikana, kun asuin vielä synnyinkaupungissani Petroskoissa. Tutummaksi Sortavala ja sen lähiseutu tuli 1990-luvulla, kun kävin siellä suomalaisten turistien, viranomaisten ja liikemiesten mukana tulkin ja matkaoppaan ominaisuudessa Suomesta käsin. 2000-luvulta alkaen olen ollut kiinnostunut rajaseuduista tutkijana. (Ks. esim. Davydova \& Pöllänen 2010.) 
Nykyinen kotikaupunkini Joensuu sijaitsee Sortavalasta 140 kilometrin päässä ja yli kahdenkymmenen Joensuun vuoteni aikana myös Sortavala on tullut osaksi "reviiriäni".

\section{VOITONPÄIVÄ NYKY-VENÄJÄN TÄRKEIMPÄNÄ KANSALLISENA JUHLANA}

Neuvostoaikana kiistaton kansallispäivän ja -juhlan asema oli vallankumouspäivällä, jota vietettiin marraskuun seitsemäntenä päivänä juhlakulkuein. Voitonpäivällä oli siihen nähden alisteinen asema. Neuvostojärjestelmän romahdettua Venäjällä on alkanut kansallisen historian, muistopäivien ja -juhlien muutoksen aika, joka koskee myös koko itäistä Keski-Eurooppaa (Gabovitsh 2015; Miller \& Lipman 2012; Muižnieks 2011; Verdery 1999; Zhurzhenko 2011). Nyky-Venäjällä neuvostoajoilta peräisin olevat juhlat ovat edelleenkin suosituimpia, vaikka jotkut niistä ovat kokeneet suuria muutoksia, ja niiden lisäksi on tullut uusia, Venäjän valtiollisuutta vahvistavia sekä ortodoksikirkon juhlapäiviä (ks. Makarkin 2015).

Voitonpäivän juhla, samoin kuin suuren isänmaallisen sodan (Neuvostoliiton ja Venäjän oma nimitys osallistumiselleen toisessa maailmansodassa, 22.6.19419.5.1945) muisto ovat nyky-Venäjän tärkeimpiä kansallista identiteettiä ja kansallista yhtenäisyyttä luovia elementtejä, joita valtio käyttää ideologisessa työssään. (Dubin 2004; 2005; 2006; Gudkov 2004.) Voitto sodassa on kiistaton kansallista ylpeyttä nostattava tapahtuma, jota 1980-1990-luvuilla tapahtuneet paljastukset neuvostohistorian väärentämistä ja vaientamista vaiheista (ks. Miller 2012) eivät pystyneet horjuttamaan.

Voiton juhlinta on alusta alkaen ollut valtaapitävien erityishuomion kohteena ja kansallisen identiteetin luomisen väline. Sen merkitys on muuttunut vuosikymmenien saatossa. Mihail Gabovitsh (2015) jakaa voitonpäivän juhlimisen muutokset kolmeen periodiin: varsinaisesta voitonpäivästä vuoteen 1965 , jolloin päivä oli julistettu vapaapäiväksi, vuodesta 1965 Neuvostoliiton hajoamiseen ja neuvostojälkeiseen juhlintaan (juhlinnan kuvauksesta ks. myös Andreev \& Bordjugov 2005; Bordjugov 2015; Dubin 2004 ja 2005; Shtsherbakova 2012; Tumarkin 2003).

Nykyjuhlinnan ymmärtämisessä merkitykselliseksi nousee 1960-1970-luvulla muodostunut juhlaperinne. Vuonna 1965 voiton 20-vuotispäivän juhlinnassa välittyivät brezhneviläisen ajan ideologiset tehtävät. Voittoa ruvettiin käyttämään järjestelmän "pyhittämiseen": nykypäivä esitettiin koko kansan sodanaikaisen uhrauksen huipentumana. Sotaa edeltävästä Neuvostoliiton messiaanisesta myytistä inmiskunnan edelläkävijänä ja työtätekevien "pelastajana" siirryttiin toisenlaiseen kertomukseen: Neuvostoliitto oli huikealla uhrauksellaan pelastanut Euroopan fasismilta. Samaan vaiheeseen kuuluu arjen ja kaupunkien julkisen tilan kyllästäminen sankaruuden, uhrauksen ja voiton symboleilla: sankarikaupunkien arvon myöntäminen Moskovalle, Leningradille, Volgogradille, Kiovalle, Sevastopolille, Odessalle ja Brestin linnakkeelle sekä tuntemattoman sotilaan hautojen ja muistomerkkien rakentaminen kaupunkien keskustoihin ja niiden merkitseminen "ikuisilla tulilla". Valtavia muistomerkkikomplekseja rakennettiin ympäri maata käyttäen samantyyppistä tyyliä, hahmoja ja symboliikkaa. 1960-1970-luvulla tuotettiin myös merkityksellisimmät sota-aiheiset elokuvat, joissa mielikuva 
sodasta ja sen veteraaneista luotiin nykypäivän moraaliseksi mittapuuksi. Koko maahan muodostui yhtenäinen sotamuiston symbolinen ja fyysinen tila sekä tulkinta sodasta.

Lyhyeksi jääneen perestroikan ja 1990-luvun aikaisen sodan uudelleenarvioinnin vaiheen jälkeen 2000-luvulla sen juhlinnassa on palattu neuvostoaikaisten merkitysten ja symbolien käyttöön. Sosiologi Boris Dubinin (2005) mukaan voiton 60-vuotispäivän juhlinnan poliittisessa käytössä oli palattu brezhneviläisiin tavoitteisiin ja keinoihin: erilaistuneen ja eriarvoistuneen yhteiskunnan symboliseen tuottamiseen "koko kansana", joka yhdistyy maan johtoon. Tämä saavutettiin rakentamalla yksinkertaistettuja mielikuvia "meistä" ja "vihollisista", vahvasta valtiosta ja sen vahvasta johtajasta. Samalla vaiennettiin sodan virallistetussa muistossa 1980-1990-luvuilla tapahtunut katkos ja voiton virallistetun muiston avulla rakennettiin yhteys vaiheeseen, joka edelleenkin esitetään Neuvostoliiton ja Venäjän "kulta-aikana". (Ks. myös Gudkov 2005.)

2000-luvulla Venäjän historian viralliset tulkinnat ovat siirtyneet yrityksistä yhdistää tsaari- ja neuvostomenneisyys (ks. Fossato 2006) uuteen historiapolitiikkaan, joka perustelee Venäjän itsenäistä suurvalta-asemaa ja hyväksyy totalitaarisen vaiheen saavutukset sekä esittää niiden uhrit perusteltuina. (Miller 2012.) Kulttuuriantropologi Sergei Oushakine (2013) korostaa, että 2000-luvulla tapahtunut voitonpäivän juhlinnan tyylin muutos viestittää muutosta historiakuvassa: menneisyyttä ei haluta käsitellä, vaan suhtautuminen siihen muokataan ensisijaisesti kokemus- ja tunnepohjaiseksi, ja itse historia esitetään fragmentaarisena eikä suurten linjojen kokonaisuutena. Sodan ja voiton kokemus ja mielikuva ikään kuin halutaan siirtää tähän päivään järkiperäisen pohdinnan sijaan.

Itse voitonpäivän juhlintaa on toisaalta tutkittu suhteellisen vähän ja siinäkin keskitytty etupäässä valtion järjestämään toimintaan suurkaupungeissa tai television välityksellä tuotettuihin malleihin. Toisaalta voitonpäivän juhlaa on ollut tapana tarkastella nimenomaan juhlan ja voiton mielikuvan poliittisen käytön näkökulmasta. (Gabovitsh 2015.) Venäläisessä tutkimuksessa sitä arvioidaan usein valtion muokkaaman "sankarillistetun" muiston ja perhemuistojen vastakkainasetteluna, virallisena juhlintana ja kansanjuhlana (esim. Andreev \& Bordjugov 2005; Shtsherbakova 2012; Pruss 2005). Kuitenkin jo neuvostoaikana voitonpäivän juhlinnassa oli alueellisia eroja, eikä sen muoto koskaan ollut täysin vakiintunut, vaan historioitsija Mihail Gabovitshin (2015) mukaan se on muotoutunut kompromissina eri aikakausien ja ryhmien intressien yhteensovittamisessa.

Neuvostojälkeisen juhlinnan kontekstit ovat monimuotoistuneet entisestään, ja juhlan sekä voiton symboliikan merkitys on hyvin erilainen Venäjällä, entisissä neuvostotasavalloissa ja maissa, joihin neuvostojälkeisten muuttoliikkeiden myötä on muodostunut huomattavia venäjänkielisiä vähemmistöjä. Itse Venäjän sisälläkin juhlaa vietetään eri tavoin (esimerkiksi Tshetshenian pääkaupunki Groznyssä ja Pietarissa). Neuvostojälkeisenä aikana myös neuvostoajoilta peräisin olevia patsaita ja sotamuistoon viittaavia ympäristöjä on kohdeltu eri tavoin. (Ks. Gabovitsh 2015,2016 .) Myös kansan näkemys voitosta ja siihen viittaavasta juhlasta on muuttunut. Sosiologi Aleksei Levinsonin (2015) mukaan siitä on hälvenemässä 
muisto sotauhreista, kaatuneista sotilaista ja "koko kansan" kärsimyksestä, ja se on muuttumassa yhä enemmän Venäjän sotakunnian ylistysjuhlaksi.

Tämä artikkeli on kirjoitettu vuonna 2013 aloitetun kansainvälisen projektin tuloksena. Hankkeessa seurattiin voitonpäivänjuhlintaa 23 eri kaupungissa 11 eri maassa. (Ks. Gabovitsh 2015; 2016.) Tarjouduin tekemään tutkimusta Sortavalassa, koska olen tutkinut rajaseutujen ja muuttoliikkeiden muodostamia ylirajaisia tiloja ja rajaa jo pitkään (esim. Davydova 2009; Davydova \& Pöllänen 2010). Vietin vuoden 2013 voitonpäivän juhlan 9. toukokuuta Sortavalassa. Seurasin juhlaa, valokuvasin sen kulkua ja äänitin puheita. Haastattelin myös joitakin juhlan osallistujia. Juhlassa ja sen jälkeen tein muistiinpanoja. Nämä kaikki yhdessä juhlan vietosta kertovien internet-julkaisujen kanssa muodostavat tämän artikkelin aineiston. Toisen aineiston muodostavat äänitykset ja kuvat, jotka olen tehnyt syyskuun 28. päivänä 2014, kun Sortavalassa juhlittiin "fasistimiehittäjistä vapautumisen päivää". Sain haltuuni myös tämän juhlan kulun käsikirjoituksen. Myöhempi aineisto on toissijainen tätä artikkelia ajatellen, mutta näen kuitenkin voiton- ja vapautumisjuhlien liittyvän toisiinsa.

\section{TEOREETTISET LÄHTÖKOHDAT}

Tarkasteluani ohjaavat teoreettiset näkökulmat keskittyvät kulttuurisen (kollektiivisen) muistin tuottamisen keinojen analyysiin. Ensinnäkin kiinnitän huomiota kaupungin sotamuistoa tuottaviin paikkoihin ja niiden käyttöön juhlinnassa. Kulttuurin- ja historiantutkija Aleksandr Etkind (2015, 254-255) painottaa, että nyky-yhteiskunnissa on mahdotonta puhua joidenkin tapahtumien välittömästä muistamisesta, sillä muisti on aina välittynyttä, medioitunutta. Hän ehdottaakin muistin tutkimuksen huomion siirtämistä muistin ympärille muodostuvista kollektiivisuuksista muistin tuottamisen tapoihin. Etkindin (2015) mukaan muistin kulttuurista tuotantoa voi tarkastella tekemällä jaon muistin "laitteistoon" (hardware) ja "ohjelmistoon" (software). Hänen mukaansa kulttuurinen muisti on "multimediakollaasi", joka muodostuu niiden yhteispelissä: pysyvät, tilaan sijoitetut muistomerkit ja muistoihin viittaavat paikat yhdessä muuttuvien historiankirjoituksen ja taiteen tuottamien narratiivien kanssa toimivat jatkuvasti muuttuvana ja samalla pysyvänä kulttuurisen muistin tuottamisen välineistönä. Elinympäristöjemme näkyvät, aineelliset muistin paikat välittävät ja muokkaavat kulttuurista ja kollektiivista muistia, ja samalla ovat itse muokkauksen ja uudelleentulkinnan kohteina. (Esim. Davydova 2008; Smith 2008; Verdery 1999.)

Myös juhlan paikka on mukana kulttuurisen muistin ja yhteisön tuottamisessa. Kaupunkitila ja sen kansalliseen muistiin viittaavat paikat otetaan juhlan aikana käyttöön eri tavalla kuin arkena. Ne, jotka ottavat osaa juhlintaan, asettuvat hierarkkisesti julkiseen kaupunkitilaan luoden näin käsitystä eri ihmisten asemasta paikallisessa (arvo)yhteisössä. Juhlassa kaupunkitila jakautuu "arkiseen" ja "pyhään", missä juhlinta tapahtuu. Osallistujalle muodostuu käsitys kaupungin "kansallisesta" maantieteestä, joka voi poiketa tuntuvasti muista kaupunkitilaan tavallisesti liittyvistä mielikuvista (ks. Izotov 2008). Juhlinnassa tietyt paikat otetaan käyttöön, niihin liitetään tietyt perinteet ja tavat sekä tunteet. Niiden käytöstä voi syntyä myös kamppailua. (Ks. Tiwari 2010; Strelnikova 2011.) 
Kansallinen juhla tapahtumana on Etkindin (2015) jaottelun mukaista muistin "ohjelmistoa". Se on toistuva, muodollinen ja pakottava rituaali, joka toteutuu siihen varatuissa paikoissa. Rituaali esittää luonnollisena hegemonisen yhteiskunnallisen vallan, muovaa yleisöjen tunteita sekä käsityksiä hyvästä ja pahasta. Se esittää usein "kansakunnan perustamistapahtumaa", ja siihen on sisäänrakennettu sen muistamisen malli. Rituaali itsessään on muistin järjestyksen ja siihen sisäänrakennetun temporaalisuuden välittämistä (Feuchtwang 2010, 298). Historioitsija Paul Connerton (1989) tuo esille, että kansallisten rituaalien välityksellä yhteisön näkökulmasta muistamisen arvoiset asiat omaksutaan reflektoimattomalla tavalla eli sisäistetään ruumiin tasolla. Rituaaleissa inmiset kokoontuvat yhteen ja "kuviteltu yhteisö" ruumiillistuu joukossa samoin toimivia, liikkuvia, puhuvia tai laulavia inmisiä. Rituaali ei niinkään "ilmaise" yhteisön arvoja, vaan pikemminkin tuottaa niitä ja yhteisöjä performatiivisesti, toistuvasti samaan aikaan vuodesta toiseen. Connerton (mts.) seuraa austinilaista performatiivisuuden käsitystä: performatiivit ovat todellisuutta tuottavia tekoja, eivätkä vain representoi jotain niiden ulkopuolella olevaa. Rituaalissa performatiivisesta historian kertomuksesta tulee osa osallistujien ja katsojien ruumiillista muistia ruumiin liikkeinä, ryhtinä, ryhmittymisenä, asentoina, koristeluina ja tuntemuksina. (Ks. myös Feuchtwang 2010.)

Muistin tuottamiseen keskittyvän näkökulman lisäksi toinen tärkeä teoriaperinne, johon kiinnityn, liittyy nationalismin konstruktiiviseen tutkimustraditioon. (Anderson 2001; Billig 1995; Gillis 1994; Hobsbawm 1984). Kansallisen juhlan keskeinen funktio on "muistuttaa" kansalaisia heidän "oikeasta" tai tavoiteltavasta identiteetistä ja samalla tehdä heidät osallisiksi siitä (re-membering). Sotaan tai muuhun kansakunnan kannalta tärkeäksi nostettuun tapahtumaan viittaavassa juhlassa muistilla on keskeinen rooli, mihin termi muistojuhla (commemoration) viittaa. Valtion hallitsemassa juhlassa luodaan mielikuva siitä, minkälaisina valtio haluaa kansalaisensa nähdä, mikä on kansakunta, ketkä siihen kuuluvat, mitkä ovat kansallisen yhteisön historia ja arvot. Kansallinen juhla on keskeinen instrumentti kansakuntien kuvittelussa. (McCrone \& McPherson 2012; Skey 2012.) Kansalliset juhlat ovat muuttuvia ja useimmiten politisoituja, ne rytmittävät kansallista kalenteria ja rakenteistavat myös arkea. Verrattuna "banaaliin", huomaamatta jäävään arkipäivän nationalismiin, niissä on vahva tunteisiin vetoava elementti, "ekstaattinen" nationalismi. (Nyyssönen 2012; Paasi 2015).

Analyysissäni seuraan politiikantutkija Heino Nyyssösen $(2012,138)$ ajatusta erottaa toisistaan muistin (memory) politiikka ja muistojuhlan viettämisen (commemoration) politiikka. Muistin politiikan käsite viittaa kamppailuun muistettavan tapahtuman merkitysten tuottamisesta. Kansallisessa juhlassa muistettavan tapahtuman, sen ajankohdan ja viettotapojen määrittely voidaan nähdä muistojuhlan politiikkana, mikä on muistin politiikkaa kapeampi osa-alue. (Nyyssönen 2012.) Historioitsija Jay Winter (2010) korostaa, että kansalliset muistojuhlat ovat aina moniäänisiä, ja niiden tarkastelussa on pidettävä mielessä ihmisten toimijuus. Juhlien näkeminen pelkkänä tietyn historian tai muiston mielikuvan syöttämisen välineenä on yksipuolista. Kaikilla juhlaan osallistuvilla voi olla omia motiiveja ja tavoitteita juhlassa. Muistojuhlan viettämisen politiikkaa voivat harjoittaa eri toimijat näin ajaen kansallispäivän merkitysten muutosta. Onnistuneessa kansallisessa 
juhlassa saavutetaan kansallisen yhteisön integroituminen, mihin pyrkivät niin valtaapitävät kuin kansalaisetkin (Gabovitsh 2015).

Nimenomaan muistin muutoksen tutkimisen tärkeyttä korostaa myös Aleksandr Etkind (2015, 258-259) kehittämällään "muistitapahtuman" termillä. Muistitapahtuma on nähtävä erillisenä siitä historiallisesta tapahtumasta, johon se viittaa ja jolle se tarjoaa tulkinnan. Muistitapahtuma voi "kolonisoida" itse historiallisen tapahtuman luoden tapahtumasta uudenlaisen mielikuvan. Muistitapahtumassa tapahtuu kuitenkin repeämä aikaisempaan historian tulkintaan, joka voi muotoutua monessa yksittäisessä tapahtumassa tai teossa. Muistitapahtuma kiinnittää huomiota ilmiöihin, jotka vievät tätä muutosta eteenpäin.

Kuten aikaisemmissakin kirjoituksissani, pidän tärkeänä tuoda esille myös oman positioni. Historian tutkija Jorma Kalela (2001) muistuttaa, että samoin kuin muutkin historian käyttäjät, tutkija on oman yhteiskuntansa ja historiansa tuottama, ja vaatii tutkijalta "oman todellisuuskäsityksensä ja kielensä järjestelmällistä erittelyä". Näkökulmaani tutkimiini ilmiöihin määrittelee maahanmuuttajakokemukseni ja transnationaalisuutta käsittelevä teoreettinen keskustelu (Davydova 2009; ks. myös De Cesari \& Rigney 2015). Maahanmuuttajuuteen liittyvää sosiaalista ja kulttuurista prosessia voidaan käsitteellistää ylirajaisten sosiaalisten ja kulttuuristen suhdeverkostojen muodostumisena. Hybridille ylirajaiselle tilalle ja sen kokemukselle on ominaista konfliktisuus (Davydova 2008), ja kahden kansallisen tilan ongelmallinen risteytyminen maahanmuuttajan kokemuksessa. Muistin tarkastelu transnationaalisuuden näkökulmasta kiinnittää huomiota siihen, kuinka lähtökohtaisesti ylirajaisilla sosiaalisilla ja kulttuurisilla kentillä luodaan erilaisia rajoja (Khagram \& Levitt 2008, 5). Näen oman positioni myös hedelmällisenä: katse "ei sieltä eikä täältä", ilman takana olevaa yksiselitteistä "omaa yhteiskuntaa" voi huomata sen, mikä muuten jäisi itsestään selväksi "vaatteisiin tarttuneeksi" historiatiedoksi ja kansalliseksi muistoksi.

\section{JUHLAN MAANTIETO}

Voitonpäivän juhlat pidetään tavallisesti kaupunkien keskustoissa, sodalle omistetun muistopatsaan tai ikuisen tulen vieressä. Juhlaan kuuluu virallisia puheita ja jonkintyyppinen paraati tai kulkue. Sortavalassa haastattelemieni ihmisten kertomusten mukaan (haastattelu 1 ja 4 ) juhlaa on aina pidetty pääkadulla: ensin joukkokokous armeijan kutsuntatoimistoa vastapäätä, ja sitten on marssittu Karjalankatua pitkin länteen päin neuvostosotilaiden muistomerkille, jonne on laskettu seppeleitä. Neuvostoaikana siis muistin tilaksi muodostui suora kaupungin keskustasta muistopatsaalle.

Vuonna 2013 juhla pidettiin perinteisessä paikassa vakiintuneen kaavan mukaan. Ensin oli joukkokokous juhlapuheineen ja paraati Karjalankadulla armeijan komissariaatin rakennusta (Karjalankatu 21) vastapäätä, mistä kaikki osallistujat kulkivat Karjalankatua pitkin neuvostosotilaiden sankarihaudalle Bondarevin (ent. Helyläntie) ja Karjalankadun yhtymäkohdassa, minne on pystytetty surua symboloiva muistopatsas. Joukkokokouksen paikan ja patsaan välinen matka on noin 
700 metriä; kulkue eteni alamäkeä ja ikään kuin törmäsi risteyksessä olevaan patsaaseen. Patsaan juurella pidettiin taas puheita ja laskettiin seppeleitä.

\section{Kuva 1. Muistopatsas neuvostosotilaiden sankarihaudalla ${ }^{4}$}

Noin kolme metriä korkea muistopatsas esittää pää alas painautuneena toisen polven varassa seisovaa neuvostosotilasta ja naista lapsi sylissä. Realistiset hahmot on maalattu valkoisiksi ja nostettu inmisen korkuiselle mustalle jalustalle. Patsaan viesti on helposti luettavissa: suremme tulevien sukupolvien puolesta elämänsä uhranneita. Mustalla kiiltävällä kivilaatalla päällystettyyn jalustaan on kultaisin kirjaimin kaiverrettu joukkohautaan haudattujen sotilaiden nimet ja suurin kirjaimin teksti: Maamme vapauden ja itsenäisyyden puolesta taisteluissa kaatuneille uljaille neuvostosotilaille. Sankarihautaan on haudattu 705 vuosina 1941-1944 kaatunutta sotilasta. Patsas pystytettiin vuosina 1956-1957, ja samaan aikaan samantyylisiä patsaita pystytettiin muillekin Laatokan Karjalan alueen sankarihaudoille (Krasnolutski 2012, 278-279).

Neuvostojälkeisissä kaupungeissa neuvostoaikaisia muistopatsaita on kohdeltu eri tavoin: niiden hajottamisesta ja siirtämisestä (esim. Tallinnassa ja Vilnassa) säilyttämiseen ja palauttamiseen (kuten Venäjällä) (ks. Oushakine 2011; Williams 2008; Smith 2008). Kaikkialla nämä toiminnot ovat olleet sidoksissa rakennettavien kansakuntien identiteettipolitiikkoihin ja niihin liittyviin kamppailuihin. Myös Sortavalassa neuvostoaikaiset patsaat ovat kokeneet eri vaiheita. Pitkään ne ovat olleet ränsistyneessä kunnossa, ja monet Sortavalan seudun 1950-luvulla pystytetyt patsaat ovat edelleenkin vailla korjausta, kuten Läskelän kylässä sijaitsevat sotilasta ja surevaa äitiä esittävä patsas sekä vieressä oleva Aleksandr Pushkinin patsas. Bondarevin ja Karjalankadun risteyksessä oleva patsas on korjattu vuonna 2010 (Karelinform 2010). Kipsiosat maalattiin ja jalusta sai uuden kiveyksen. Patsaan taakse on rakennettu eräänlainen muistokuja, johon on pystytetty hautakiviä muistuttavia muistolaattoja. Muistolaattojen runomuotoiset tekstit ylistävät muistettavia sankareita ja uhreja: kaatuneita sotilaita, Leningradin saarrossa olleita, keskitysleirien alaikäisiä vankeja, Afganistanin sodassa sotineita ja rajavartijoita. Kujan päähän on pystytetty iso puinen ortodoksinen risti.

\section{Kuva 2. Muistokuja patsaan takana}

Vakkosalmen rannassa oleva yksittäistä sotilasta esittävä Aljosha-patsas ${ }^{5}$ on kokenut toisenlaisen muutoksen. Vuonna 1990 tehdyssä Neuvosto-Karjala-dokumentissa kerrottiin, kuinka Sortavalassa valmistauduttiin laulujuhliin saapuvien suomalaisten vastaanottoon. Koulun edessä olevan neuvostosotilaan muistopatsaan rynnäkkökivääri oli lyöty alas ja sen tilalle tehty kipsikukkakimppu. ${ }^{6}$ Ränsistynyt

\footnotetext{
$4 \quad$ Kuvat liitteessa artikkelin lopussa. Klikkaa linkkiä.

5 Aljosha-nimi neuvostosotilaan patsaaseen viittaavana juontaa juurensa neuvostoaikana vuonna 1966 ilmestyneeseen lauluun, joka kertoi Aljosha-nimisestä patsaasta Bulgariassa. Tallinnan "Pronssisotilasta" on myös kutsuttu Aljoshaksi. Haastattelemani nuoret puhuivat sortavalalaisesta Aljoshasta ja vertasivat sitä Murmanskissa oleviin patsaisiin. Aljosha-patsaista ks. Münch 2013.

$6 \quad$ Kyseisen aikakauden pyrkimys dialogiin sotamuistosta välittyy parhaiten Pitkärannan ja Suojärven tien risteykseen suomalais-venäläisin voimin vuonna 2000 pystytetyssä Surun risti -patsaassa,
} 
Aljosha oli vielä vuonna 2009 ilman rynnäkkökivääriä, muttei sillä ollut enää kukkiakaan?. Patsasta on viime vuosina korjattu, mutta huolimattomasti: kipsin alta näkyy palautetun rynnäkkökiväärin puurunko, valkoinen maali on paikoin tippunut alas.

Päällisin puolin muuttumattomilta näyttävät, stalinistista "suurta" tyyliä ja neuvostoaikaista muistamisen kaanonia edustavat muistopatsaat kantavat muistin politiikkojen eri vaiheiden jälkiä: "Aljosha" 1990-luvun lännelle (Suomelle) avautumista ja pääpatsas taas kansallisten sankareiden listan laajentumista ja sotamuiston liittämistä ortodoksikirkkoon. Toisaalta 1950-luvulla pystytetyt muistopatsaat tuttuudessaan osallistuvat synnyinmaan kansallistetun maantiedon luomiseen. Sortavalan patsaat - sekä pääpatsas että koulun eteen pystytetty - edustavat Stalinin aikaista kaupunkipatsastyyliä. Ne valmistettiin sarjatuotantona, ja puistot ja aukiot täyttyivät valkoiseksi maalatuilla realistisilla, suhteellisen pienikokoisilla ihmishahmoilla: jalkapalloa pelaava pioneeri, Pushkin ja sureva sotilas kuuluvat edelleenkin itsestään selvästi maisemiin, vaikka niitä on purettu ja niille pilailtu perestroikan aikana ja 1990-luvulla. Tämän tyyppisiä patsaita on Laatokan Karjala täynnä: niitä on Ruskealan, Helylän, Kaalamon, Läskelän, Värtsilän, Haaplammen ja Pitkärannan sankarihaudoilla. Nämä banaalit, huomioimatta jäävät patsaat ovat helposti tunnistettavia, kotoisia ja itsestään selviä kaupunkiympäristön osia, jotka luovat samalla ideologisen jatkuvuuden tunnetta. (Etkind 2015; Oushakine 2011; Strelnikova 2011.)

Kaupunkitila oli myös koristeltu muistorituaalia varten: Karjalankadun varrella olevan kirjakaupan ja Kirovin aukion varrella sijaitsevan lastenkirjaston ikkunoissa näkyi sota-aikaisia propagandajulisteita, rakennustyömaata ympäröivälle aidalle oli kiinnitetty onnittelujulisteita ja ilmoituksia juhlinnasta, erään kerrostalon seinällä isolla näytöllä näytettiin sota-aikaisia kuvia ja onnitteluja voiton päivän johdosta. Kaupungin koristelussa neuvostoaikainen juhlan estetiikka yhdistyi pyrkimykseen ikään kuin palauttaa sota-aika tähän päivään ja näin taata ihmisten eläytyminen juhlaan.

Kuva 3. Kaupungin koristelua

\section{VIRANOMAISTEN JÄRJESTÄMÄ JUHLA}

Jo ennen juhlan alkua Karjalankadun jalkakäytävät olivat täynnä juhlavasti pukeutuneita ihmisiä. Monilla oli rinnuksilla, laukkujen hihnoissa tai lastenvaunuissa Yrjön nauhat. ${ }^{8}$ Joukkokokous alkoi ja päättyi Venäjän kansallislaululla, joka on peräisin

joka esittää suomalaista ja venäläistä ristiin nojaavaa poikiaan surevaa äitiä.

$7 \quad$ Kiitän Aleksandr Izotovia tästä tiedosta.

8 Pyhän Yrjön nauha (georgievskaja lenta) on musta-oranssi kunniamerkkinauhaa muistuttava nauhanpätkä, jota levitetään Voitonpäivän juhlan yhteydessä ilmaiseksi. Kampanja alkoi vuonna 2005 RIA Novostin ja Opiskelijaliitto-nimisen kansalaisjärjestön aloitteesta. Nauha tulkitaan isänmaallisuuden tai konformismin osoitukseksi, mutta sen historiallisuus on kyseenalaistettu. Nauha on sekoitus tsaarin- ja neuvostoaikaista kunniamerkkiperinnettä ja kuuluu nykyhallinnon käyttämiin identiteettisymboleihin. 
Stalinin ajoilta ja jonka sanoitusta on hieman muutettu vuonna 2000. Joukkokokouksessa esiintyneet sotaveteraani, kaupunginhallinnon ja veteraanineuvoston edustajat, Sortavalan kaupunginjohtaja ja Karjalan lainsäädäntökokouksen jäsen puhuivat kaavamaisesti voitosta fasismista käyttäen neuvostoajoilta tuttuja kliseitä: sodassa voitettiin ruskea rutto, voiton hinta oli suuri, yllämme on ollut rauhan taivas jo 68 vuotta, meidän velvollisuutemme on muistaa veteraaneja, alaikäisiä fasismin vankeja, saarrossa olleita, ja olemme ikuisesti kiitollisuuden velkaa heille, jotka ovat lahjoittaneet meille elämän, meidän on oltava kaatuneiden muiston arvoisia.

\section{Kuva 4. Viralliset puheet joukkokokouksessa}

Kulttuurintutkija Lev Gudkov (2005) kirjoittaa, että tämäntyyppinen "voiton kieli" on muotoutunut virallisesti hyväksyttyjen voiton mielikuvien muuttuessa stereotypioiksi neuvostoaikaisessa kulttuuris-ideologisessa tuotannossa. Tällainen puhe on antanut valtavalle inmisjoukolle omanlaisensa korkeiden kollektiivisten tunteiden ja lyyrisen valtiollisuuden kielen, joka jähmettyi kivenkovaksi 1970-luvun puolivälissä. Valtaosa venäläisistä pystyy tänä päivänä puhumaan voitosta ainoastaan tällä kielellä (Gudkov 2005). Voiton mielikuvassa tärkeä rooli on myös unohduksella: siitä on puristettu pois niin sanottu "luutnanttitotuus" eli sodan jälkeen ja 1960-luvun kirjallisuudessa ilmestyneet sotaa johtaneen neuvostovaltion epäinhimillisyydestä kertovat teokset, tai pohdiskelu sotilas- ja siviiliuhrien tarpeellisuudesta ja vähemmistöjen kohtelusta tai naisten osallistumisesta sotaan. (Fieseler 2005; Nikonova 2005; Shtsherbakova 2012.) Nykyvenäläiselle sodan muistolle on edelleenkin ominaista kahtiajakoisuus: virallinen, ritualisoitunut, jähmettynyt ja medioitunut "suuren voiton" myytti, ja perheiden sisällä välittyvä muisto, jossa sota mielletään ennen kaikkea kärsimyksenä. (Pruss 2005; Shtsherbakova 2005.) 2000-luvulla voitonpäivän juhlinnassa on etupäässä kansalaisaloittein pyritty kuromaan tämä repeämä umpeen ja tuomaan esimerkiksi kaatuneiden nimet ja kuvat mukaan juhlintaan (ks. Gabovitsh 2015). Kuitenkin Sortavalassa viranomaisten järjestämässä juhlassa on säilynyt neuvostotyylinen tapa puhua voitosta.

Joukkokokouksessa esiintyi myös koululaistyttö, joka ainoana kaikista puhujista puhui "meidän Sortavalasta, meidän Karjalasta". Muut taas puhuivat "voitosta fasismista", eivätkä millään tavalla täsmentäneet, mitä "fasismi" merkitsi Sortavalassa, ketä vastaan täällä on sodittu, milloin ja miten. Paikallinen sota suomalaisia vastaan ei tullut kertaakaan esille missään julkisessa puheessa. Tyttö mainitsi karjalaiset "sankaripartisaanit", joita vielä neuvostoaikana on käytetty luomaan mielikuvaa isänmaan puolesta elämänsä antaneesta nuoresta, ja tämän piti nimenomaan nuorissa luoda velvoitteita valtiota kohtaan. Folkloristi Svetlana Adonjeva (2001, 125-153) on tutkinut neuvostoihmisen "kulttuurisia imperatiiveja", ajattelua ja toimintaa ohjaavia mentaalisia rakennelmia. Hän on selvittänyt, kuinka 1970-luvulla nuoruutta viettäneet ymmärsivät imperatiivin "kuolema isänmaan puolesta". Adonjevan mukaan sankarillinen kuolema johtaa kuolemattomuuteen, joka takaa ikuisen muiston sankariteosta. Toisaalta sankarikuolema sodassa velvoittaa seuraavia sukupolvia elämään kaatuneiden puolesta ja elämään nimenomaan kunniakkaasti 
eli valtion ideologiaa noudattaen. Tytön sanat siitä, etteivät sankaripartisaanit ehtineet kokea perheen perustamisen onnea, liittyvät taas tulkintani mukaan nykyvaltion biopolitiikkaan, joka "velvoittaa" kansalaisia synnyttämään uusia kansalaisia.

\section{Kuva 5. Lapsiosastoja paraatissa}

\section{Kuva 6. Veteraaneja ohjataan kolonnaan}

Joukkokokouksen jälkeen alkoi paraati, johon osallistui pari "joukkuetta", joista toinen ilmeisesti koostui rajavartijoista ja toinen kutsuntatoimiston työntekijöistä sekä muutamasta pienemmästä joukosta lapsia. Lapsilla oli univormut päällä ja jotkut heistä näyttivät suorastaan säälittäviltä isoissa sotilaspaidoissaan. Sotilaat marssivat yhtä jalkaa, mutta lapset eivät onnistuneet siinä, vaikka yrittivätkin kovasti. Tätä kaikkea säesti kovaääninen neuvostoaikainen marssimusiikki. Paraatia seurasi juhlan vetäjän "meidän panssaritekniikaksi" kutsuma kulkue: muutama lasten carting-auto liehuvine Neuvostoliiton ja Venäjän lippuineen. Sitten kadun varrella seissyt väki järjestäytyi ajokaistalle niin, että kolonnan eturiviin ohjattiin kymmenkunta hyvin vanhaa ja hidasliikkeistä veteraania, heidän peräänsä kaupunginhallinnon ja Sortavalan ammattikoulun väkeä banderolleineen, ja heidän perässään saivat kävellä kaikki muut. Nykyvenäläisessä käytännössä on yleistä velvoittaa kaupunkien tai valtion budjetista palkkansa saavia osallistumaan valtion tueksi järjestettyihin joukkotilaisuuksiin. Sortavalan voitonjuhlassa kaupunginhallinnon työntekijät ja Sortavalan ammattikoulun työntekijät ja opiskelijat kulkivat joukkokokouksen paikalta sankarihaudalle kylttien alla osoittaen, että he ovat organisoidusti mukana juhlassa. Virallisen juhlan runsas osallistujamäärä oli näin turvattu, vaikka haastattelemani inmiset korostivat, että juhlassa on aina ollut paljon väkeä. Toisaalta jotkut epäilivät, etteivät kaikki osallistujat ole paikallisia.

Rivistö käveli Karjalankatua alas muistopatsaalle, missä laskettiin järjestäytyneesti seppeleitä patsaan juurelle. Patsaan edessä pidettiin myös surujumalanpalvelus. Kun kaikki seppeleet oli laskettu, inmiset viettivät vielä jonkin aikaa patsaan edessä ja hajaantuivat ympärillä olleisiin kauppoihin tai nousivat Karjalankatua ylös Nikolain kirkon eteen pystytetylle Agitbrigadalle ${ }^{9}$. Sana viittaa sota-aikaisiin agitaatiojoukkoihin ja niiden järjestämiin konsertteihin. Kirkon edessä olevalle nurmikolle oli laitettu näyttämö, iso armeijan teltta, kenttäkeittiö, puolustusasema konekivääreineen sekä kaksi isoa pöytää, joille oli asetettu sota-aikaisia aseita, kypäriä sekä muita esineitä. Monet jäivät katsomaan näitä ja sitten siirtyivät syömään tattaripuuroa kenttäkeittiöstä ja kuuntelemaan konserttia. Ylempänä Karjalankadulla oli menossa toinen konsertti, missä lapset tanssivat ryhmätansseja. Sinne riitti vain muutamia katsojia, ilmeisesti lasten vanhempia.

Seurasin juhlallisuuksia nelisen tuntia, ja lähdin sateisesta kaupungista pois iltapäivällä. Juhlasta jäi ristiriitainen vaikutelma. Juhla oli selvästi kaupunginhallinnon,

$9 \quad$ Agitbrigada on pieni ammatillinen tai harrastajaryhmä, joka konserttimuodossa kommentoi ajankohtaisia tapahtumia. Tämä toiminta kehitettiin 1920-luvulla ja se oli erityisen suosittua toisen maailmansodan aikana. Agitaatiojoukot viihdyttivät sotilaita rintamalla ja kohensivat heidän taisteluhenkeään. Tämänkin käsitteen ja sen ympärille rakennetun paikan mukaan tuominen juhlaan ikään kuin lähensi sota-aikaa nykypäivään. 
veteraanineuvoston ja armeijan komissariaatin yhdessä ohjaama. Kaupungin laitosten työntekijät olivat ilmeisesti velvoitettuja osallistumaan siihen. Samalla kuitenkin vaikutti siltä, että läsnäolijat olivat vilpittömästi osallisia siinä ja juhla oli tehty hallinnon, kirkon edessä olleen Agitbrigadan, katsojien ja pappien yhteisvoimin. Juhlasta puuttui loisto ja mahtipontisuus, johon katsojat ovat tottuneet Moskovasta televisioitujen juhlallisuuksien ${ }^{10}$ kohdalla. Sen sijaan katukuvan silmiinpistävä ränsistyneisyys, vanhusten ja lasten keskittynyt uutteruus paraatissa ja konserteissa, sekä yleinen vaikutelma, että kaikki tuntevat toisensa, loivat vaikutelman juhlasta, joka kokosi yhteen paikalliset asukkaat ja loi osallistujista yhteisön. Voitonjuhla kaikille lapsuudesta asti tuttuna, hyväksyttynä, problematisoimattomana rituaalina vaikutti tuottavan yhteisöä yhteisen muistin pohjalta. Juhlaan osallistuvista näytti rakentuvan toivotulla tavalla kansallistettuja subjekteja (McCrone \& McPherson 2012; Skey 2012).

Toisaalta juhlassa oli joitakin silmiinpistäviä ristiriitaisuuksia. Esimerkiksi virallisista puheista puuttui kokonaan maininta paikallisesta sodasta, ainoastaan lukiolaistyttö mainitsi joitakin neuvostoaikaiseen sankaripanteoniin kuuluneiden "sankaripartisaanien" nimiä ja puhui "meidän Sortavalan vapauttamisesta". Siitä, että Sortavalassa sotaa käytiin Suomea vastaan, tai että alueet saatiin Neuvostoliitolle sodan tuloksena, ei sanottu sanaakaan. Toisaalta puhuttiin, että nykypolvien täytyy muistaa, mutta mitä ja ketä, ei sen tarkemmin määritelty.

Kansalliset juhlat ja rituaalit tarjoavat tilan ja tilaisuuden osallistua niihin odotetulla ja hyväksytyllä tavalla, liittää yksityinen ja paikallinen kansalliseen, ja lisäksi ne järjestävät paikallisen tilan ja ajan kansalliseksi (Nyyssönen 2012; McCrone \& McPherson 2012). Koko rituaalisen juhlan koreografia, puheet korokkeelta, paraati, kulkue joukkokokouspaikasta patsaalle ja seppeleiden lasku, ovat reflektoimatonta, vuosi vuodelta toistuvaa, "luonnollista". (Connerton 1989, Feuchtwang 2010.) Niissä yhdistyy sotaparaatin ja hautajaiskulkueen ainekset. Rituaali artikuloi yhteisön arvojärjestelmän, muistuttaa niistä, jotka ovat "uhranneet itsensä" nykyisen kansallisen yhteisön puolesta. Juhlassa on mukana myös kuolema ja kuolleet ruumiit, joita kunnioitetaan viemällä sankarihaudalle seppeleitä, ja lisäksi sankarit siunataan myös kirkon toimilla. Juhlassa yhdistyy neuvostoaikainen käsitys "ikuisesta elämästä", joka saavutetaan uhraamalla itsensä yhteisön puolesta, uskonnolliseen käsitykseen ikuisesta elämästä kuoleman jälkeen. (Adonjeva 2001, 125-153.)

10 Televisio on nyky-Venäjällä tärkein kansakuntaa luova väline. Kaikki valtakunnalliset televisiokanavat ovat tavalla tai toisella nykyhallinnon ohjauksessa. Televisio määrittelee poliittisten ja uutisohjelmien kautta päivän "agendan" ja sankarit, määrittelee keskustelun tyylin ja luo tuottamiensa sarjojen ja viihdeohjelmien kautta mielikuvia historiasta. Venäläisen "telekansakunnan" tuottamisesta ovat kirjoittaneet esim. kulttuurintutkijat Boris Dubin, Vera Zvereva ja Lev Gudkov, jotka ovat analysoineet, kuinka 2000-luvun televisiotuotannossa on yhdistetty mielikuvia neuvosto- ja tsaarinajan imperiumeista. Dubin (2006) korostaa, että televisiolähetyksissä valtaapitävien seremonioista luodaan tarkoituksella välimatkaa valtaapitävien ja massojen välille, eli tuotetaan sivustakatsojaa eikä kansalaista. Toisaalta mielestäni viime aikoina poliittista agendaa on alettu välittää "massoille" hyvin pelkistetyssä ja emotionaalisessa muodossa suurten joukkonäytösten välityksellä, joihin johtajat ottavat osaa. (Ks. myös Oushakine 2013.) Toisaalta voitonpäivä on 2000-luvulla yhä enemmän arvioitu "yhteiseksi", "koko kansan" juhlaksi, ja siihen "koukuttamiseen" keksitään yhä uusia symboleja ja toimintamuotoja. Esimerkiksi Kuolematon rykmentti -liike järjestää ympäri Venäjää kulkueita, joissa sodassa kaatuneiden sotilaiden jälkeläiset marssivat kantaen kaatuneiden valokuvia. 
Koska voitonjuhla on vuoden ainoa tilaisuus, jossa kaikki kaupunkilaiset voivat kävellä yhteisenä kulkueena ja tehdä neuvostotyylisiä kollektiivisia tekoja, se on selvästi nostalginen juhla. Voitonpäivä ikään kuin korvaa menetetyt neuvostoaikaiset vapun- ja vallankumouspäivän kulkueet, joihin osallistuminen oli pakollista ja samalla itsestään selvää ja jotka tuottivat kyseenalaistamatonta yhteisöllisyyttä, "sosiaalista ruumista". (Yurtshak 2014, 125-135; Adonjeva 2009, 261-281.) Sortavalassa näkyi, että juhla on toisaalta virallinen, toisaalta kansanjuhla, joka yhdistää samassa marssissa ja toiminnassa kaikki osallistujat. Juhlassa kaikki tiesivät asemansa ja roolinsa, juhlan säännöt ja toimivat niiden mukaan. Kaikki haastattelemani ihmiset, niin nuoret, keski-ikäiset kuin vanhat, korostivat sitä, että tätä juhlaa on juhlittu samalla tavalla "aina". Toisaalta joukko yli 80-vuotiaita naisia muisti, että sitä on ruvettu juhlimaan 1960-luvulla, eikä sitä ennen voittoa ollut heidän sanojensa mukaan tapana juhlia. ${ }^{11}$

Kaikki neuvostojuhlat olivat valtion ohjaamia: niiden viettämiseksi kehitettiin keskitetysti käsikirjoitukset, skenaariot, joita piti seurata (ks. Heikkinen 1985; Davydova 2005; Kelly \& Sirotinina 2008). Haulla "voitonpäivän skenaario" venäjänkielinen Internet näyttää noin miljoona osumaa. Nykyoloissa juhlien järjestäminen on kaupallistunut, ja juhlia sekä niiden skenaarioita tuottavat monenlaiset alan yritykset. Voitonpäivän juhlien skenaarioita tuottavat myös täydennyskoulutuksessa olevat tai patrioottisesta kasvatuksesta vastaavat opettajat (Bratkin 2015). Ne on tarkoitettu eri ryhmille, kuten päiväkoteihin, kouluihin, vanhainkoteihin, nuorisolle ja veteraaneille, mutta ne seuraavat yhdenmukaista kaavaa ja koostuvat samoista usein runomuotoisista moduuleista: lasten runoja, veteraanien onnitteluja ja haastatteluja, musiikkia ja kiitollisuuden ilmausta. Teksteissä on paljon vakiintuneita kaavamaisia ilmaisuja. Kaupunginjuhlien skenaarioista vastaavat tavallisesti kaupungin viranomaiset, ja voitonpäivän juhlinta on vahvasti ohjattua. Esimerkiksi voiton 60-vuotisjuhlan juhlimiseksi oli presidentin käskyllä perustettu "Venäjän Voitto-järjestelykomitea" (Poljan 2005), jolla oli laajat valtuudet ohjata kaikkea juhlintaan liittyvää toimintaa. Sama komitea ohjasi voiton 70-vuotisjuhlavuoden valmisteluja ja patrioottisen kasvatuksen ohjelmien kehittelyä. Myös Sortavalan saksalais-fasistisilta miehittäjiltä vapauttamisjuhla (28.8.2014) pidettiin hallussani olevan skenaarion mukaan. Pääjuhlat ovat siis tiukasti ohjattuja ja käyttävät edelleenkin standardisoitua, usein mahtipontista ja paatoksellista "voiton kieltä". Sortavalassa pidettiin voitonpäivänä monta muutakin tilaisuutta, jotka olivat intertekstuaalisessa suhteessa pääjuhlaan: niiden mainosten otsikoissa toistuivat samat vakiintuneet ilmaisut ja voi olettaa, että ne oli järjestetty vakiintuneen skenaarion mukaan.

Joukkokokouksen virallisista puheista panin merkille, että juhlittavien henkilöiden kirjoa veteraanien lisäksi on neuvostoajoilta laajennettu ja heitä nimetään samalla tavalla kuin sosiaalisia etuuksia saavia ryhmiä: Leningradin saarrossa olleet, fasistileirien alaikäiset vangit, työn veteraanit. Kaikilla näillä ryhmillä on oletettu oma sota-ajan kokemus, vaikka ei välttämättä itse rintamalta tai taisteluista. Näihin voivat lukeutua myös ne, jotka itse sodan aikana oli suljettu "neuvostokansasta" pois.

11 Juhlinnan historiasta ks. Tumarkin 2003; Shtsherbakova 2010; Dubin 2004; 2005; juhlan merkityksestä Adonjeva 2001, 125-153; Bordjugov 2015; Gabovitsh 2015; 2016. 
Nykyjuhla pystyy sulkemaan sisäänsä laajasti ne, jotka voivat yhtyä sodanaikaiseen kärsimykseen. Esimerkiksi haastattelemani vainoista kärsineen karjalaismiehen iäkkäät tyttäret tunsivat olevansa monin tavoin osallisina paikalliseen juhlaan: Sortavalan ensimmäisinä asukkaina ja juhlittavaksi nostettuun byrokraattiseen "työn veteraanien" kategoriaan kuulumisen myötä (haastattelu 4).

Haastatteluissa kuitenkin tuli esille, että juhlan luonne on muuttunut. Vaikka neuvostoaikana voitonpäivän juhlinta olikin valtion vahvasti ohjaamaa ja sen tarkoituksena oli ylistää ennen kaikkea valtiota, sodan kokeneille se oli myös omien kokemuksien ja menetyksien muistelujuhla. Nykyisin tämä merkitys on väistymässä sukupolvien vaihtuessa. (Ks. Levinson 2015.) Haastattelemani vanhat naiset (haastattelut 1 ja 4) valittivat, että juhlasta on tullut liian iloinen, sitä ei vietetä "kyynel silmässä", kuten ennen. Näin he viittasivat 1970-luvulla tehtyyn lauluun, jossa voitonpäivän tunnelma kiteytetään fraasiin "se on iloa kyynel silmässä". Päinvastoin, haastattelemani nuoret (haastattelu 2) puhuivat siitä, kuinka iloisia ja onnellisia he ovat tämän juhlan johdosta. Kun pyysin heitä kertomaan minulle, mitä tämä juhla heille merkitsee, ensimmäisenä he käyttivät fraasia "kiitos vaarille voitosta" viitaten nykyaikaiseen lauluun ja sen nimisiin kampanjoihin ympäri Venäjää (ks. Brown 2015). Vaikuttaa siltä, että populaarikulttuurin tuotteet kehystävät eri sukupolvien käsityksiä juhlan merkityksestä. Nuoret kertoivat vuoden 1945 tapahtumista niin, etteivät puhuneet Neuvostoliitosta ollenkaan, vaan puhuivat Venäjän armeijasta, Venäjän voitosta ja sotineista venäläisistä. Vaikuttaa siltä, että virallinen juhla on myöhäisneuvostoaikaan verrattuna riisuttu ylenpalttisesta surusta, ja ainakin nuoret käsittävät sen ensisijaisesti Venäjän voiton riemujuhlana.

\section{RUOHONJUURITASON PATRIOOTTISTA TOIMINTAA JUHLASSA}

Kun seppeleet oli laskettu patsaalle, monet palasivat Karjalankatua pitkin keskustaan ja liittyivät Nikolain kirkon eteen pystytetyn Agitbrigadan tarjoamiin tapahtumiin. Näyttämöllä pidettiin konsertti, joka toimi taustana muille "huvituksille", joista suurimman kiinnostuksen herättivät isot pöydät täynnä sodanaikaisia kypäriä, aseita, ammuksia ja muita sota- ja neuvostoaikaisia esineitä. Pöytien ympärillä parveili lapsia ja aikuisia, jotka koskettelivat esineitä, kuvasivat niitä ja itseään niiden kanssa, keskustelivat niistä toistensa kanssa sekä kyselivät niistä pöytien vieressä seisoneilta miehiltä, jotka vastasivat kysymyksiin ilmeisen mielihyvin.

\section{Kuva 7. Etsintäpartion pöytä Agitbrigadassa}

\section{Kuva 8. Agitbrigadan konsertti}

Keskustelin näyttelyä esitelleen miehen kanssa, ja hän kertoi minulle, että esineet kuuluivat Tuokslahden koulun museolle. Mies oli etsintäpartion ${ }^{12}$ johtaja, ja hän kertoi partion toiminnan alkamisesta ja koulun museon perustamisesta. Nykyään

12 Niin sanottu etsintäliike muotoutui Neuvostoliitossa 1980-luvulla. Etsintäpartiot etsivät sodassa kaatuneita, selvittävät heidän henkilöllisyyksiään ja vaalivat sodan muistoa. He esimerkiksi huolehtivat muistopatsaista ja pystyttävät uusia. Valtio tukee nykyisin tätä toimintaa osana väestön patrioottista kasvatusta, ja se on hyvin järjestettyä. Esimerkiksi Karjalan tasavallassa toimii noin 30 erityyppistä etsintäpartiota ja useita niitä yhdistäviä organisaatioita. (Ks. Poisk.) 
tällaisia museoita on muissakin Sortavalan piirin kouluissa, ja osa kokoelmasta on esillä kaupunginkirjastossa. ${ }^{13}$ Viranomaisten lisäksi etsintäpartio vaikuttaa olevan hyväksytty ja tärkeä toimija virallisessa voitonpäivän juhlassa.

Kuten edellä tuli esille, joukkokokouksen puheista puuttui kokonaan paikallisuus lukiolaistytön puhetta lukuun ottamatta. Sodasta ja fasismista puhuttiin hyvin yleisellä tasolla. Etsintäpartion johtajan haastattelupuhe taas oli täynnä paikallisia nimiä ja paikallisten taistelujen tietämystä. Esimerkiksi kun kysyin, löydetäänkö täältä suomalaisten sotilaiden jäännöksiä, hän vastasi:

Ei. Meillä oli taisteluita vain vuonna 41, eli puolustustaisteluja. Meillä puolustustaisteluja. Eli taistelu, meikäläiset perääntyivät, taistelu, meikäläiset perääntyivät. Niin, sen takia suomalaiset poimivat omansa. Meikäläiset makaavat siellä edelleen. (Haastattelu 5.)

Suomalainen kaatuneiden huolto järjesti ruumiiden toimittamisen ja hautaamisen kotikuntien hautausmaille, kun taas kaatuneet neuvostosotilaat haudattiin taistelupaikoille, jos ehdittiin. Tämän takia Pohjois-Laatokan metsistä löydetään edelleen paljon sotilaiden jäänteitä. (Blinnikka 2004; Gavrilov 2012; Kuzmina 2012.) Kaatuneiden sotilaiden etsintätyö tarjoaakin vapaaehtoisille tilaisuuden saada henkilökohtainen kosketus sotaan ja paikallisen sotahistorian omakohtaiseen tunnepitoiseen kokemiseen. Etsintäpartion johtajan kertomus partion toiminnasta käsitteli hyvin konkreettisia tapahtumia: sotilaiden ruumiiden jäänteiden etsintää, niiden tunnistamista, heidän jälkeläistensä etsintää ja vierailujen järjestämistä Sortavalaan. Etsijät (poiskoviki) sananmukaisesti rakentavat yhteyden sukupolvien välille, "nostavat" sodan jäljet tähän päivään. Samalla he esiintyvät Sortavalan seutujen "isäntinä", paikallisuuden asiantuntijoina.

Kaikki nämä tapahtumat ovat tunnepitoisia ja tuottavat käsitystä ikään kuin verisiteen kautta muodostuvasta yhteydestä sota-ajan ja nykykansakunnan välillä. Tässä toiminnassa ollaan välittömästi tekemisissä niiden kanssa, jotka ovat "uhranneet itsensä isänmaan puolesta". Kaatuneet Puna-Armeijan sotilaat saavat tässä toiminnassa uuden poliittisen elämän. (Verdery 1999.) Yleisesti ottaen kaatuneiden ja kaatumapaikkojen käsittely tarjoaa kosketuspintoja pyhään - niin kansallisiin pyhiin uhreihin kuin uskontoon kuuluvaan käsitykseen pyhästä. Kun kansakunnan puolesta kaatuneita siunataan ja haudataan ortodoksisin menoin, luodaan mielikuvaa isänmaallisuudesta, joka vastaa tämän päivän venäläistä ideologiaa.

Etsintätyössä syntyy myös omia, epämuodollisia muistamisen tapoja, jotka vetävät mukaan ulkopuolisiakin.

Eräässä taistelupaikassa me nostimme, paljonko, yli 30 taistelijaa, ja tien reunalle pystytimme muistomerkin. Siinä oli vielä muottilaudoitus paikalla, se oli maalaamaton, me tulimme kolmen päivän kuluttua, siinä oli jo kukkia. Siitä asti siellä on aina ollut kukkia, laitetaan vodkalaseja, kolikoita, talvisin joulukoristeita, joo. Ihmi-

13 Koulumuseoita alettiin perustaa Neuvostoliitossa 1920-luvulla, ja ne yleistyivät 1950- ja varsinkin 1970-luvulla. Nykyään koulumuseot vaikuttavat olevan taas nousussa, koska niiden nähdään olevan tärkeä patrioottisen kasvatuksen keino. (Ks. Kozlova 2014.) 
sillä on sellaista kiinnostusta, anteeksi, en osannut odottaa, rehellisesti sanoen, että tästä tulee niin kysytty. On ihmisiä jotka menevät toukokuun yhdeksäntenä varta vasten sinne, eivätkä tänne, ja siellä viettävät tämän juhlan. (Haastattelu 5.)

Tämän tyyppiset ruohonjuuritason muistopaikat (grassroots memorials, ks. Margry \& Sánchez-Carretero 2011) ovat yleistyneet Pohjois-Laatokan seudulla 2000-luvulla. Yleisimpiä ovat auto-onnettomuuksien paikoille pystytetyt muistomerkit, mutta myös etsintäpartion johtajan kertoman tapaiset sotamuistomerkit. Hän kuvasi myös muistamisen tavan, joka on peräisin pikemmin yksityishaudan ortodoksissävyisestä kansanomaisesta muistorituaalista kuin julkisesta muistamisriitistä virallisine puheineen ja seppeleiden laskuineen. Matkallani Sortavalaan huomasin ennen Ruskealan kylää oikealla puolen tietä yhden omatekoisen muistomerkin. Ison paasikiven päälle oli laitettu kaksi auton rengasta, joiden väliin oli pistetty pitkä koivurunko. Pystyssä olevaan keppiin oli sidottu punainen t-paita, ja kivelle oli maalattu telat. Tämä rakennelma näytti tieltä käsin neuvostoliittolaiselta panssarivaunulta, jonka piippu osoitti Suomea.

\section{Kuva 9. Itse tehty muistomerkki Ruskealan kylässä}

Epämuodolliset muistamisen käytännöt ovat yleisiä, sosiaalisesti hyväksyttäviä ja synnyttävät yhteisöllistä toimintaa (Margry \& Sánchez-Carretero 2011). Näin ne voivat tuntua vastakkaisilta valtiolliselle, ylhäältä päin orkestroidulle, "paikattomalle" muistamiselle. Ne tuottavat paikallisuutta, jossa kuolema isänmaan puolesta muuttuu henkilökohtaisesti koetuksi, sukulaishaudalla harjoitettavien muistamisen käytäntöjen kaltaisiksi. Samalla side paikkaan muuttuu "verisiteeksi" ja sota "isänmaalliseksi".

Niin voitonpäivän juhlassa kuin Sortavalan vapautusjuhlassa etsintäpartion jäsenet olivat pukeutuneet sota-aikaisiin sotilas- ja upseeripukuihin, ${ }^{14}$ jotka edustivat autenttista sota-ajan esineistöä. Tällä he ikään kuin toivat sota-ajan todellisuuden tähän päivään. (Oushakine 2013.) Yhdistettynä sortavalalaisiin rakennuksiin, joissa edelleenkin näkyvät ammusten jäljet, ja näyteikkunoita koristaviin sotaajan julisteisiin tämä toimi eräänlaisen valikoivan aikakoneen tavoin: kaupunki oli merkitty neuvostokaupungiksi sodan virallisen tulkinnan mukaan. Samantyyppistä sota-ajan nykypäivään tuomista harjoittaa vuonna 2012 Tomskissa alkanut voitonpäivänä pidettäviä kulkueita järjestävä Kuolematon rykmentti -liike (Bessmertnyi polk), jonka järjestämissä kulkueissa kaikki halukkaat voivat kantaa kaatuneen esi-isänsä kuvaa. Liikkeen verkkosivulla kerätään tietoja kaatuneista sotilaista. (Moypolk 2015. $)^{15}$ Suuria mustavalkoisia sotilaiden valokuvia nostetaan väkijoukon

14 Konsertin juontajanaisen päällä oli miesten sotilasunivormu. Vaikka toiminnassa on myös tyttöjä mukana, sitä johtavat miehet ja se rekonstruoi miesten toiminta-alaa sodassa, taisteluja. Naisten sota näyttää jäävän tästä toiminnasta pois. Etsintäpartioiden kiinnostus sota-aikaan on valikoivaa ja myötäilee valtiollista patrioottisen kasvatuksen linjaa edistäen mielikuvaa sankarikuolemasta ja vapaaehtoisesta itsensä uhraamisesta. Tässä mielessä se on erisuuntaista kansalaisjärjestö Memorialin toiminnan kanssa, joka järjestämissään koululaisille suunnatuissa kirjoituskilpailuissa selvittää sota-ajan perhemuistoja. Näitä välittävät tavallisesti vanhat naiset, ja ne kertovat perheiden ja naisten selviytymisestä. (Ks. Shtsherbakova 2005, Pruss 2005.)

15 Kuolemattoman rykmentin verkkosivu kutsuu kaikkia "jotka arvostavat voittaja-rintamamiesten muistoa" liittymään mukaan ottamalla sotilaan valokuva ja tulemalla 9. toukokuuta marssiin. 
yläpuolelle, ja näin kaatuneet tai kuolleet sijoitetaan symbolisesti elävien joukkoon. Voitonpäivän juhlassa Sortavalassa tätä käytäntöä ei näkynyt, mutta vapautusjuhlassa rivi nuoria tyttöjä kantoi Kuolemattoman rykmentin banderollia. Sen sijaan voitonpäivän juhlassa jokainen osallistuja oli voinut kirjoittaa sotineen esi-isänsä nimen Agitbrigadan luona olleelle ilmoituspylväälle. Etsintäpartion järjestämä Agitbrigada tarjosi tilaisuuden toisenlaiseen, autenttisempaan ja yksilöidympään kansalliseen juhlaan liittymiseen kuin viranomaisten juhla, mutta sodasta välittyvät mielikuvat vahvistivat silti virallisesti hyväksyttyjä muistamisen tapoja.

\section{ORTODOKSIKIRKKO KANSALLISESSA JUHLASSA}

Paikallisten asukkaiden, valtion, kunnan ja koulujen ohella ortodoksikirkko oli näkyvä toimija voitonpäivän juhlassa Sortavalassa. Juhlan aattona keskustassa kävellessäni inmettelin Karjalankadun ylle pingotettuja banderolleja: "Hyvää voitonpäivää, rakkaat sortavalalaiset", ja "Kristus on noussut kuolleista, totisesti noussut!". Voitonpäivän tervehdys oli kirjoitettu vakiintuneeseen tyyliin punaiselle kankaalle, ja sitä koristi Yrjön nauha, pääsiäistervehdystä puolestaan koristivat kulitsan ja kananmunien kuvat. Keskustassa oli runsaasti muitakin julisteita, jotka kertoivat voitonpäivän juhlallisuuksista (esimerkiksi Voitto elää jokaisen sydämessä -konsertti), sodanaikaisia julisteita ja pääsiäistervehdyksiä. Joukkokokouksessa armeijan komissariaatin kohdalla kirkon edustajia ei ollut, mutta seppeleiden laskutilaisuudessa he pitivät surujumalanpalveluksen (Ladoga-Sortavala 2013). Sortavalan vapauttamisjuhlassa 28.9.2014 kirkolla oli miltei johtava rooli: koko seremonia pidettiin kirkon edessä, sitä ennen oli jumalanpalvelus, ja lyhyiden virallisten puheiden jälkeen sankarivainajien siunaaminen ja maahan saattaminen päämuistomerkin sankarihautaan tapahtui ortodoksipappien johdolla.

Etsintäpartion Agitbrigada oli kentällä kirkon edessä. Jossakin vaiheessa konsertin juontaja rupesi puhumaan siitä, että vuonna 1945 toukokuun kuudentena oli "suuri, valoisa pääsiäinen", ja että vuonna 2013 oltiin lähellä sitä, kun pääsiäinen oli viidentenä päivänä toukokuuta. Hän kutsui ensin kirkkoherran ja sitten "meidän pappimme, isä Andrein ja isä Antonin" pitämään tervehdyspuhetta konserttinäyttämölle. Pappien puheet olivat pidempiä kuin hallinnon edustajien puheet joukkokokouksessa, mutta aiheet samoja: meidän tulee olla kiitollisia iso- ja isoisoisillemme heidän uroteostaan; siitä, että he ovat puolustaneet synnyinmaatamme valloittajilta. "Tehtävämme on säilyttää muisto tästä päivästä, koska vain se kansa on suuri, joka säilyttää muistoa omasta historiastaan". Puhe päättyi sanoihin "Hyvää voitonpäivää, Kristus on noussut kuolleista!", ja juontaja yhdessä yleisön kanssa vastasi innokkaana: "Totisesti noussut!" Toisen papin puhe oli osoitettu nuorisolle: "Haluaisin kääntyä nuorisomme puoleen, että nuoriso ei pilkkaisi, vaan että he muistaisivat, että he muistaisivat kyynel silmässä, eikä silloin enää kukaan suhtaudu juhlaan ilman hartautta". Pappien puheessa yhdistyi vanhahtava kirkollinen ylätyyli neuvostoaikaiseen voiton kieleen. Papit huutelivat aina välillä yleisölle pääsiäistervehdysten lisäksi "Hyvää voitonpäivää", "Hurraa", ja väki yhtyi kaavamaisten tervehdysten huutamiseen. Tässä tilaisuudessa valtiollinen juhla oli ristiriidat-

Vaikka sivulla puhutaan muiston vaalimisesta, siitä(kin) suljetaan pois ne, joiden kokemuksia ja muistoja sodasta ei voi tulkita sankarillisiksi. 
tomasti liitetty kirkolliseen ja tälle liitokselle oli luotu oma historiansa viittaamalla vuoteen 1945. Muistaminen näyttäytyi koko rituaalin keskeisenä performatiivisena sanana ja tavoitteena. Sodan muisto esitettiin jonakin pyhänä, tarpeellisena ja pakollisena ja epäilys tuomittiin. Kuitenkin taas kerran itse muiston sisältö jäi ikään kuin nimeämättä, itsestään selväksi ja samalla julkilausumattomaksi.

\section{Kuva 10. Pappeja Agitbrigadan lavalla}

Nyky-Venäjällä ortodoksinen kirkko yhtyy yhä enemmän valtioon, vaikka edelleenkin muodollisesti valtio on erotettu kirkosta (Solodovnik 2013) ja valtion tärkeimmässä juhlassa ja rituaalissa kirkolla oli näyttävä rooli. Sodan liittäminen kirkollisiin juhliin ei ole sortavalalaisten pappien keksintö. Vuoden 2013 voitonpäivän tervehdyksessä Venäjän ortodoksikirkon johtaja Patriarkka Kirill on muun muassa sanonut, että sota päättyi voittoon ja pääsiäiseen sen takia, että se oli alkanut Venäjän pyhien ylösnousemuksen päivänä 22. kesäkuuta 1941. Lisäksi hän on verrannut tuota aikaa tähän päivään sanomalla, että tänä päivänä Venäjä käy yhtä vaikeaa taistelua itsenäisyydestään kuin sota-aikana (Mirvam 2013). Tällä hän sijoitti oman puheensa Venäjän johdon ja tiedotusvälineiden luomaan kuvaan siitä, että "länsi" ja sen arvojärjestelmä uhkaavat Venäjän "perinteisiä" arvoja ja itse Venäjän olemassaoloa. Neuvostoaikainen voiton myytti on siis muokattu uuteen ideologiseen järjestelmään sopivaksi.

\section{LOPUKSI: MUISTIN JA JUHLINNAN POLITIIKKAA RAJASEUDULLA}

Tarkastelin artikkelissa Sortavalassa vietettyä voitonpäivän juhlaa muistojuhlan politiikan (Nyyssönen 2012) näkökulmasta. Historiaan viittaava ja historiakuvaa muokkaava kansallispäivä on osa laajempaa valtion johdolla harjoitettua muistin politiikkaa, joka muodostaa toimintakentän monille toimijoille. Kollektiivisen sotamuiston tuottajana nykyjuhlinta on Etkindin (2015) metaforan mukaan kollaasimaista. Siinä on mukana niin neuvostoaikaisia kuin neuvostojälkeisenä aikana kehitettyjä symboleja ja merkityksiä. Voitonpäiväjuhlaa käsittelin paikallisena tapahtumana, jossa eri toimijat tuottavat mielikuvia sodasta ja voitosta yhteisvoimin (Gabovitsh 2015).

Juhlan sisällä tapahtuvassa muistin tuottamisessa on mukana niin materiaalinen ympäristö (juhlan "laitteisto") kuin eri muodoissa esiintyvät narratiivit (ohjelmisto) (Etkind 2015). Juhlan perinteiseksi viettopaikaksi on muodostunut kaupungin pääkatu sen päässä sijaitsevine muistomerkkeineen. Koko muistomerkin alueen 2010-luvulla toteutettu muokkaus heijastaa valtion lisääntynyttä huomiota sotamuistoa ja sankarivainajia kohtaan, sankarijoukon laajentumista ja ortodoksikirkon nousua muistin vaalijaksi ja hallitsijaksi valtion rinnalle. Sotamuisto legitimoi nykyvaltiota ja valtio sekä viranomaiset hallitsevat juhlapaikkoja ja juhlanviettoa.

Fyysisessä ympäristössä tapahtuvaa juhlintaa tarkastelin muuttuvana, temporaalisena muistitapahtumana, joka viittaa historialliseen tapahtumaan, sen aikaisempiin tulkintoihin ja luo uutta tulkintaa historiasta (Etkind 2015). Kaiken kaikkiaan voi sanoa, että sotaa muistavien sukupolvien poistuessa voitonpäivän juhlasta on hälvenemässä ylenpalttinen suru, ja sen tilalle tulee ilo ja ylpeys. Juhla ei niin- 
kään pyri muistuttamaan itse sodan kokemuksesta, vaan rituaalin muoto pysyy myöhäisneuvostoaikaisessa kaavassa ja jatkaa 1960-1970-luvuilla muotoutunutta "voiton myyttiä" (Dubin 2005; Gudkov 2005; Tumarkin 2003). Juhlan kulku seuraa vakiintunutta rituaalia (Connerton 1989; Feuchtwang 2010) joukkokokouksineen, juhlapuhujineen, "voiton kielineen", musiikkeineen, kulkueineen ja seppeleiden laskuineen. Tämä rituaali yhdessä neuvostosotilaiden muistomerkin kanssa muodostaa pysyvän ja tutun, neuvostoajoilta peräisin olevan juhlan perustan. Tältä osin juhla osallistuu kansallistetun sodan ja voiton mielikuvan uusintamiseen. Sota esitetään sotana "fasisteja vastaan" ja heistä saavutettuna voittona. Tästä mielikuvasta on Sortavalan seuduilla käyty sota Suomea vastaan suljettu pois.

Neuvostojälkeisenä aikana juhlinnassa on tapahtunut kuitenkin lukuisia muutoksia. Vaikuttaa siltä, että viranomaisten järjestämä juhla on jossain määrin menettämässä auktoriteettiasemaansa. Tähän viittaa heidän puheensa kaavamaisuus ja muuttumattomuus, tai paraatin "keventyminen" neuvostoaikaiseen verrattuna. Toiset juhlan tekemisessä mukana olevat tahot, nimittäin etsintäpartio ja ortodoksikirkko, vaikuttavat vievän viralliselta juhlalta sen emotionaalisen latauksen omiin toimintoihinsa. Etsintäpartio osallistuu näkyvimmin "muistin affektiiviseen hallintaan" (Oushakine 2013) tuomalla juhlintaan sodan "autenttisuuden". Etsintä- ja rekonstruktiopartioiden toiminta on performatiivista, visuaalista, konkreettista, se vetoaa tunteisiin ja tarjoaa mahdollisuuden eläytyä, ja sitä kautta se tempaa ihmisiä mukaan, "isänmaallistaa" heitä. Toisaalta etsintäpartion toiminta luo kontaktin sota-ajan paikallisiin tapahtumiin. Etsintäpartion näkyvä osallistuminen juhlan viettoon ei ollut ristiriidassa sodan virallisen tulkinnan kanssa, vaan sen järjestämä Agitbrigada tarjosi juhlayleisölle tunteisiin vetoavaa ja toiminnallista osallistumismuotoa, joka viittasi ikään kuin suoraan sota-aikaan, eikä neuvostoaikaiseen voittomyyttiin.

Ortodoksikirkon toiminta juhlassa oli suunnattu virallisen sotamuiston vahvistamiseen, ja siten kirkko tuki valtiollista muistin politiikkaa. Toisaalta ortodoksikirkko esiintyi juhlinnassa kuolleiden ruumiiden käsittelyn ja heidän muistonsa vaalimisen luonnollisena "ammattilaisena". Vaikuttaa siltä, että ortodoksikirkko on rakentamassa itselleen selkeää roolia sotamuiston vaalimisessa. Nyky-Venäjällä sodan muistopaikat, nimittäin muistomerkit, sankarihaudat ja taistelupaikat merkitään ortodoksiristein, vaikka kaatuneet eivät olisikaan kuuluneet ortodoksikirkkoon. Tässä tapahtunut muutos kuvastaa koko Venäjän yhteiskunnan ideologisen pohjan muutosta neuvostoaikaisesta ateismista nykyvenäläiseen tilanteeseen, jossa ortodoksisella kirkolla on yhä suurempi rooli yhteiskunnallisten arvojen vahvistajana ja asettajana.

Kansalliset juhlat luovat mielikuvaa kansakunnasta ja siihen kuulumisen tavoista; ne muistuttavat kansalaisia heidän jäsenyydestään kansallisessa yhteisössä (McCrone \& McPherson 2012; Nyyssönen 2012). Sortavalan voitonpäivän juhlan analyysin perusteella voi sanoa, että kansallistettu sodan ja voiton muisto on kolonisoinut paikallisen muiston. Paikalliset muistot ovat selvästi alisteisessa asemassa kansallisessa muistohierarkiassa. Kansalaiselta siis edellytetään sodan virallisen tulkinnan omaksumista. Sota on kirjaimellisesti sortavalalaisen nyky-yhteisön muodostumisen kannalta perustavanlaatuinen tapahtuma, mutta juhlassa siitä muodostuu 
mielikuva, jossa paikallisuus on toissijaista, ellei poissuljettua. Tässä näkisin sortavalalaisen juhlan ja sotamuiston (ja siten kansakuntaan kuulumisen) selkeimmän jännitteen, joka voi periaatteessa häiritä ja horjuttaa kansallistettua sotamuistoa.

Suomen ja Venäjän välisellä rajaseudulla on kylmän sodan päättymisen jälkeen harjoitettu monenlaisia muistin politiikkoja, joita on esitetty näkyvästikin muistomerkkien, museonäyttelyiden ja erinäisten entisöintihankkeiden muodossa. Käsittelemäni kansallisen juhlan luoma sotamuisto on nykykansallisuuden luomisen yksi instrumentti Venäjällä. Se piirtää selkeät rajat "meille". Kansallistettu sodan muisto esiintyy "ekstaattisena" juhlassa ja pysyy arjessa "banaalina", itsestään selvänä. Keskusteluissani juhlan osallistujien kanssa tuli selvästi esille heidän arkensa ylirajainen luonne: toisilla on Suomessa sukulaisia, toiset toimivat tulkkeina Sortavalassa käyville suomalaisille matkailijoille, toiset erikoistuvat Sortavalan suomalaisen historian vaalimiseen. Kansallistettu sodan muisto näyttää asettuvan sille määrättyihin kalenteripäiviin.

\section{LÄHTEET}

\section{Tutkimusaineistot}

Muistiinpanot 9.5.2013

Muistiinpanot 28.8.2014

Karjalan ja Sortavalan fasistimiehittäjistä vapautumisjuhlan skenaario, 28.9.2014

\section{Äänitteet}

Haastattelu 1, Nainen, noin 80 v., 9.5.2013 haastattelija Olga Davydova-Minguet Haastattelu 2, 2 poikaa ja tyttö, 15-vuotiaat, 9.5.2913 haastattelija Olga Davydova-Minguet

Haastattelu 3, nainen, yli 50-vuotias, 9.5.2013 haastattelija Olga Davydova-Minguet Haastattelu 4, kolme yli 80-vuotiasta ja 1 noin 50-vuotias nainen 9.5.2013 haastattelija Olga Davydova-Minguet

Haastattelu 5, mies, yli 40-vuotias, 9.5.2013 haastattelija Olga Davydova-Minguet Haastattelu 6, nainen, yli 40-vuotias, 9.5.2013 haastattelija Olga Davydova-Minguet Haastattelu 7: Vitali Rystov, Serdobol-aikakauslehden kustantaja, 21.12.2014, haastattelija Olga Davydova-Minguet

Äänite Agitbrigadan konsertin puheista, 9.5.2013 tekijä Olga Davydova-Minguet Äänite Karjalan ja Sortavalan fasistimiehittäjistä vapautumisjuhlasta, 28.9.2014, tekijä Olga Davydova-Minguet 
KiRJALLisUUS

Adonjeva, Svetlana 2001: Kategorija nenastojashtshego vremeni (Antropologitsheskie otsherki). Sankt-Peterburg: Peterburgskoe vostokovedenie.

Adonjeva, Svetlana 2009: Duh naroda i drugie duhi. Sankt-Peterburg: Amfora. 2011: Miserable or Golden Karelia? Interpreting a Cross-border Excursion of Students from Finland to Russia. - Journal of Borderlands Studies 26(2): 145-159.

Anderson, Benedict 2001: Voobrazhaemye soobshtshestva. Razmyshlenija ob istokah i rasprostranenii nacionalizma. Englannin kielestä venäjäntänyt V.G. Nikolaev. Alkuperäinen teos: Imagined Communities. Reflections on the Origin and Spread of Nationalism. Moskva: Kanon-Press-C.

Andreev, Dmitri \& Bordjugov, Gennadi 2005: Prostranstvo pamjati: Velikaja Pobeda i vlast. Moskva: AIRO.

Assmann, Aleida 2014: Dlinnaja ten proshlogo: Memorialnaja kultrua $i$ istotitsheskaja politika. Moskva: Novoe Literaturnoe Obozrenie.

Billig, Michael 1995: Banal Nationalism. London: Sage.

Bordjugov, Gennadi (toim.) 2015: Pobeda-70: rekonstruktsija jubileja. Moskva: AIRO.

Björn, Ismo 2001: Suomalaisten Sortavala, Laatokan valkoinen kaupunki. - Hakamies, Pekka, Liikanen, Ilkka \& Simola, Heikki (toim.), Sortavala rajakaupunki. Joensuu: Joensuun yliopisto.. 21-36.

Blinnikka, Aulis 2004: Sotavainajiamme rajan takaa. Suomen sodissa 1939-45 kentälle jääneiden etsinnät ja muiston vaaliminen. Jyväskylä: Gummerus.

Bratkin, Dmitri 2015: 'Meetings with the veterans' as oral non-history and parareligious ceremony. A presentation given at Aleksanteri Conference in Helsinki 23.10.2015.

Brown, Judy 2015: Performativnaja pamjat: prazdnovanie Dnja Pobedy $v$ Sevastopole. - Neprikosnovennyi zapas. 2015, N. 3(101). [online] <http:// magazines.russ.ru/nz/2015/3/12b-pr.html> [10.10.2015.]

Connerton, Paul 1989: How Societies Remember. Cambridge: Cambridge University Press.

Davydova, Olga 2005: Rituaali, identiteetti ja ylirajaisuus. Joitakin ajatuksia paluumuuttajan hautajaisista. Elore 12(1). [online] < www.elore.fi/ arkisto/1 05/dav1 05.pdf $>$ [15.9.2014.]

Davydova, Olga 2008: Bronze Soldier goes Transnational: Mediascapes and the Formation of Identities in Internet Discussions. - Ethnopolitics 7(4): 391-411.

Davydova, Olga 2009: Suomalaisena, venäläisenä ja kolmantena. Etnisyysdiskursseja transnationaalissa tilassa. Joensuu: Joensuun yliopisto.

Davydova, Olga \& Pöllänen, Pirjo 2010: Gender on the Finnish-Russian Border: National, Ethnosexual and Bodily Perspective. - Virkkunen, Joni, Uimonen, Pirjo, Davydova, Olga (eds.), Ethnosexual Processes. Realities, Stereotypes and Narratives. Helsinki: Kikimora Publications. 7-25.

De Cesari, Chiara \& Rigney, Ann (eds.) 2015: Transnational Memory. Circulation, Articulation, Scales. Berlin, Boston: Walter de Gruyter. 
Dubin, Boris 2004: "Krovavaja" voina i "velikaja" pobeda. - Otetshestvennye zapiski 19(5). [online]. < http://old.strana-oz.ru/?numid=20\&article=937 > [15.9.2014.]

Dubin, Boris 2005: Bremja pobedy. Boris Dubin o polititsheskom upotreblenii simvolov. - Krititsheskaja massa 2005(2). [online]. < http://magazines.russ. $\mathrm{ru} / \mathrm{km} / 2005 / 2 / \mathrm{du} 6 . \mathrm{html}>$ [15.09.2014.]

Dubin, Boris 2006: Postoronnie: vlast, massa i massmedia $v$ segodnjashnei Rossii. - Otetshestvennye zapiski 2006(6). [online]. < http://magazines.russ. ru/oz/2005/6/2005 6 1-pr.html > [15.09.2014.]

Etkind, Aleksandr 2015: Post-Stalinist Russia: Memory and Mourning. - Kattago, Shobian (ed.) The Ashgate Research Companion to Memory Studies. Burlington: Ashgate. 251-264.

Feuchtwang, Stephan 2010: Ritual and Memory. - Radstone, Susannah \& Schwarz, Bill (eds.) Memory. Histories, Theories, Debates. New York: Fordham University Press. 281-298.

Fieseler, Beate 2005: Nisthshie pobediteli: invalidy Velikoi Otetshestvennoi voiny v Sovetskom Sojuze. Neprikosnovennyi zapas n. 2-3(40-41) [online]. < http://magazines.russ.ru/nz/2005/2/fi33.html > [14.2.2015.]

Fingerroos, Outi \& Loipponen, Jaana 2007: Uudella reitillä Karjalaan. Fingerroos, Outi \& Loipponen, Jaana (toim.) Nykytulkintojen Karjala. Jyväskylä: Jyväskylän yliopisto. 7-15.

Fingerroos, Outi 2007: Uuskareliaanit nyky-Karjalassa. - Fingerroos, Outi \& Loipponen, Jaana (toim.) Nykytulkintojen Karjala. Jyväskylä: Jyväskylän yliopisto. 16-34.

Fingerroos, Outi 2010: Karjala utopiana. Jyväskylä: Jyväskylän yliopisto.

Fossato, Floriana 2006: Virtual'naya politika i rossijskoye TV. - Pro et Contra $\mathrm{N} 4$ (33) [online]. < http://uisrussia.msu.ru/docs/nov/pec/2006/4/ ProEtContra_2006 4 03.pdf $>$ [20.3.2014.]

Gabovitsh, Mihail 2015: Pamjatnik i prazdnik: etnografija Dnja Pobedy. Neprikosnovennyi zapas. 2015, N. 3(101). [online] < http://magazines.russ. $\mathrm{ru} / \mathrm{nz} / 2015 / 3 / 9 \mathrm{~g} . \mathrm{html}>[10.10 .2015$.

Gabovitsh, Mihail (toim.) 2016 (tulossa): Pamjatnik i prazdnik. Moskva: Novoe Literaturnoe Obozrenie.

Gavrilov, Sergei 2012: Pohoronnoe delo voiny. [online]. < http://novosti-n.org/ analitic/read/1250.html> [15.3.2015.]

Gillis, John R. 1994: Memory and Identity: The History of a Relationship. - Gillis, John R. (ed.) Commemorations: The Politics of National Identity. Princeton: Princeton University Press. 3-24.

Gudkov, Lev 2005: "Pamjat" o voine i massovaja identitshnost rossijan. Neprikosnovennyi zapas 2005, No 2-3 (40-41) [online]. < http://magazines. russ.ru/nz/2005/2/gu5.html > [15.9.2014.]

Hakamies, Pekka 2005: New culture on new territory. The Karelian Isthmus and Ladoga Karelia in post-war years. - Hakamies, Pekka (ed.) Moving in the USSR. Western anomalies and Northern wilderness. Helsinki: FLS. 91-109.

Hakkarainen, Marina 2005: "We were unaware of the history. Just took... our risk". The past, cultural landscape and identity in migrant communities in Ladoga Karelia and the Karelian Isthmus. - Hakamies, Pekka (ed.) Moving in the USSR. Western anomalies and Northern wilderness. Helsinki: FLS. 42-65. 
Heikkinen, Kaija 1985: Folklorismin monet muodot. Esimerkki Neuvostoliiton juhlapeinteestä. - Tiede \& Edistys, 2/1985. 119-131.

Hobsbawm, Erik 1984: Inventing Traditions. - Hobsbawm, E. \& Ranger, T. (eds.) The invention of tradition. Cambridge: Cambridge University Press. 1-14.

Izotov, Aleksandr 2001: Suljetun rajakaupungin vaiheita. - Hakamies, Pekka, Liikanen, Ilkka \& Simola, Heikki (toim.) Sortavala - rajakaupunki. Joensuu: Joensuun yliopisto. 91-110.

Izotov, Aleksandr 2008: Magija Sortavaly: prostranstvenno-vremennyt i kulturnye obrazy goroda. - Vestnik Evrazii Acta Eurasica 39(1): 149-202.

Kalela, Jorma 2001: Historiantutkimus ja jokapäiväinen historia. - Kalela, Jorma. \& Lindroos, Ilari (toim.) Jokapäiväinen historia. Helsinki: SKS. 11-25.

Karelinform 2010 [online]. < http://karelinform.ru/?id=20856 > [15.9.2014.]

Kelly, Catriona \& Sirotinina, Svetlana 2008: "Bylo neponjatno i smeshno": prazdniki poslednih desjatiletij sovetskoi vlasti i vosprijatie ih detmi. Antropologitsheskij forum. N. 8. 258-299.

Khagram, Sanjeev \& Levitt, Peggy 2008: Constructing Transnational Studies: An Overview. - Khagram, Sanjeev and Levitt, Peggy (eds.) The Transnational Studies Reader: Intersections and Innovations. London: Routledge. 1-18.

Kozlova, Tatjana 2014: Shkolnyi muzei. - Sait Kozlovoi Tatjany Ivanovny, utshitelja istorii. [online]. < http://1979.ucoz.com/publ/shkolnyj muzej/1-1$\underline{0-17}>$ [15.9.2014.]

Krasnolutski, Aleksandr 2012: Sortavala. Sankt-Peterburg: 000 "Ploshtshad iskusstv".

Kuzmina, Galina 2012: Smotrim v voinu. - Novaja Ladoga 18.6.12. [online]. $\quad<\quad$ http://newladoga.pit.su/index.php?option=com content\&view $=$ article\&id $=678: 2012-06-18-15-36-18 \&$ catid $=35$ : soci\&Itemid $=$ 53\#comment-64 > [15.9.2014.]

Ladoga-Sortavala 2013: S dnjom Pobedy! - Ladoga-Sortavala 10.5.2013. [online]. < http://gazetaladoga.ru/gallery/day9 > [15.9.2014.]

Laine, Antti 2001: Tyhjä Karjala ja sen uudet asukkaat. - Hakamies, Pekka, Liikanen, Ilkka \& Simola, Heikki (toim.) Sortavala - rajakaupunki. Joensuu: Joensuun yliopisto. 73-90.

Laine, Antti 2005: Modernisation in the 1940s and 1950s in the part of Karelia that was annexed from Finland on 13 March 1940. - Hakamies, Pekka (ed.) Moving in the USSR. Western anomalies and Northern wilderness. Helsinki: FLS. 19-41.

Levinson, Aleksei 2015: Voina kak proshloe i kak budushtshee. - Neprikosnovennyi zapas. 2015, N. 3(101). [online] < http://magazines.russ.ru/nz/2015/3/81. $\mathrm{html}>[10.10 .2015$.

Ločmele Klinta, Procevska Olga \& Zelče, Vita 2011: Celebrations, Commemorative Dates and Related Rituals: Soviet Experience, its Transformation and Contemporary Victory Day Celebrations in Russia and Latvia. - Muižnieks, Nils (ed.) The Geopolitics of History in Latvian-Russian Relations. Riga: Academic Press of the University of Latvia. 109-138.

Loipponen, Jaana 2007: Karjala-orientalismistani, sotaleskistä, menetyksistä, tarinoista. - Fingerroos, Outi \& Loipponen, Jaana (toim.) Nykytulkintojen Karjala. Jyväskylä: Jyväskylän yliopisto. 184-201. 
Makarkin, Aleksei 2015: Protivoretshivye prazdniki novoi Rossii. Neprikosnovennyi zapas. 2015, N. 3(101). [online] < http://magazines.russ. $\mathrm{ru} / \mathrm{nz} / 2015 / 3 / 19 \mathrm{~m} . \mathrm{html}>[10.10 .2015$.

Margry, Peter-Jan \& Sánchez-Carretero Cristina 2011: Rethinking Memorialization: The Concept of Grassroots Memorials. - Margry, PeterJan, Sánchez-Carretero Cristina (eds.) Grassroots Memorials. The Politics of Memorializing Traumatic Death. New York \& Oxford: Berghahn Books, 1-50.

McCrone, David \& McPherson, Gayle 2012: Introduction. - McCrone, David \& McPherson, Gayle (eds.) National Days. Constructing and Mobilising National Identity. Basingstoke: Palgrave Mcmillan. 1-9.

Melnikova, Ekaterina 2005a (ed.): Granitsa i ljudi. Vospominanija pereselentsev Priladozhskoi Karelii i Karelskogo Peresheika. Sankt-Peterburg: Izdatelstvo Evropeiskogo universiteta $v$ Sankt-Peterburge.

Melnikova, Ekaterina 2005b: Recollections of "native land" in oral tradition of Russian settlers to Karelia. - Hakamies, Pekka (ed.) Moving in the USSR. Western Anomalies and Northern Wilderness. Helsinki: FLS. 66-78.

Melnikova, Ekaterina 2009: Svoja tshuzhaja istorija. - Neprikosnovennyi zapas 64(2). [online]. < http://magazines.russ.ru/nz/2009/2/me4.html > [15.9.2014.]

Melnikova, Ekaterina 2014: Between Local and National: Russian Local Museums from Late Socialism to Postsocialism. Presentation at the ASEEES-CESS Joint Regional Conference, at Nazarbayev University, Astana 24.5.2014.

Miller, Aleksei \& Lipman, Marija 2012: Istoritsheskaja politika $v$ XXI veke. Moskva: Novoe Literaturnoe Obozrenie.

Miller, Aleksei 2012: Istoricheskaja politika v Vostotshnoi Evrope natshala XXI veka. - Miller, Aleksei \& Lipman, Marija (eds.) Istoritsheskaja politika v XXI veke. Moskva: Novoe Literaturnoe Obozrenie. 7-32.

Mirvam 2013 [online]. < http://mirvam.org/2013/05/08/патриарх-кириллпризвал-защитить-ден/> [15.3.2015.]

Muižnieks, Nils 2008: The Geopolitics of History in Latvian-Russian Relations. Riga: Academic Press of the University of Latvia.

Münch, Felix 2013: Present Struggles with the Heroes of the Soviet Past. 'Alyosha' Monuments in Tallinn, Vienna, Plovdiv, and the Post-Communist Space. Paper presented at the ASN World Convention, Columbia University, 18-20th April 2013.

Nikonova, Olga 2005: Zhenshtshiny, voina i "figury umoltshanija". Neprikosnovennyi zapas n. 2 -3(40-41) [online]. < http://magazines.russ.ru/ $\mathrm{nz} / 2005 / 2 / \mathrm{hi32.html}>[14.2 .2015$.

Nora, Pierre 1989: Between History and Memory. Les Lieux de Mémoire. Representations 26: 7-24.

Nora, Pierre 2002: Reasons for the current upsurge in memory - Eurozine [online]. < http://www.eurozine.com/articles/2002-04-19-nora-en.html > [15.3.2015.]

Nyyssönen, Heino 2012: The Politics of Calendar. Independence Day in Finland. - McCrone, David \& McPherson, Gayle (eds.) National Days. Constructing and Mobilising National Identity. Bakingstok: Palgrave Mcmillian. 136-150. 
Onken, Eva-Clarita 2007a: The Baltic States and Moscow's May 9th Commemoration: Analysing Memory Politics in Europe - Europe-Asia Studies 59(1): 23-46.

Onken, Eva-Clarita 2007b: The Politics of Finding Historical Truth: Reviewing Baltic History Commissions and their Work. - Journal of Baltic Studies 38(1): 109-16.

Oushakine, Serguei 2011: Otstraivaja istoriju: sovetskoe proshloe segodnja. Neprikosnovennyi zapas. 2011, N. 6(80). [online]. < http://magazines.russ. $\mathrm{ru} / \mathrm{nz} / 2011 / 6 / \mathrm{u} 3 . \mathrm{html}>[15.3 .2015$.

Oushakine, Serguei 2013: Remembering in public. On the Affective Management of History. - Ab Imperio. 1/2013, 269-302.

Paasi, Anssi 2015 (tulossa): Dancing on the graves: independence, hot/banal nationalism and the mobilization of memory. - Political Geography XX.

Poisk [online]. < www.rf-poisk.ru/troop/?id=1619 > [14.2.2015.]

Poljan, Pavel 2005: Jubilei á la Glavpour? Rossijskij organizatsionnyi komitet "Pobeda" kak estestvennaja monopolija. - Neprikosnovennyi zapas n. 2-3(4041) [online]. < http://magazines.russ.ru/nz/2005/2/pp18.html > [14.2.2015.]

Pruss, Irina 2005: Sovetskaja istorija $v$ ispolnenii sovremennogo podrostka i ego babushki. - Neprikosnovennyi zapas n. 2-3(40-41) [online]. < http:// magazines.russ.ru/nz/2005/2/pr14.html > [14.2.2015.]

Pöllänen, Pirjo 2013: Hoivan rajat - tutkimus venäläisten vaimomuuttajien ylirajaisesta perhehoivasta. Helsinki: Väestöliitto.

Rajavartiolaitos 2015 [online]. < http://www.raja.fi/download/52028 rajanylitystilasto 2014.pdf?87165cc63029d288 > [14.3.2015.]

Raudaskoski, Mika 2015: Suomi ei kaipaa Tuntematonta sotilasta. - Karjalainen 11.9.2015.

Shtsherbakova, Irina 2012: Pobeda vmesto voiny? Kak skladyvalals pamjat o voine v Rossii (1945-2010 gg.) - Uroki istorii XX vek. [online]. < http:// urokiistorii.ru/current/dates/3222\#footnoteref20 snjtr4d $>$ [15.9.2014.]

Skey, Michael 2012: 'We Wanna Show 'em Who We are'. National Events in England. - McCrone, David \& McPherson, Gayle. National Days. Constructing and Mobilising National Identity. Basingstoke: Palgrave Mcmillan. 41-56.

Smith, David J. 2008: Woe from Stones: Commemoration, Identity Politics and Estonia's 'War of Monuments'. - Journal of Baltic Studies 39(4): 419-430.

Solodovnik, Svetlana 2013: Rossija: ofitsialnaja tserkov vybiraet vlast. - Pro et Contra No 3-4 (59): 6-26.

Strelnikova, Anna 2011: Kollektivnaja pamjat v gorodskom prostranstve: mesta pamjati ov Afganskoi voine. [online]. < http://www.isras.ru/files/File/Inter/06/ Strelnikova.pdf $>$ [15.9.2014.]

Tilastokeskus 2015: [online]. < http://pxnet2.stat.fi/PXWeb/pxweb/fi/StatFin/ > [30.10.2015.]

Tiwari, Reena 2010: Space-body-ritual: performativity in the city. Lanham: Lexington Books.

Tumarkin, Nina 2003: The Great Patriotic War as myth and memory. - European Review 11(4): 595-611.

Verdery, Katherine 1999: The Political Lives of Dead Bodies. Reburial and Postsocialist Change. New York: Kolumbia University Press. 
Williams, Paul 2008: The Afterlife of Communist Statuary: Hungary's Zoborpark and Lithuania's Grutas Park. - Forum for Modern Language Studies 44(2): 185-198.

Winter, Jay 2010: The performance of the Past: Memory, History, Identity. Tilmans, Karen \& Van Vree, Frank \& Winter, Jay (eds.) Performing the Past. Memory, History, and Identity in Modern Europe. Amsterdam: Amsterdam University Press, 11-34.

Yurtshak, Aleksei 2014: Eto bylo navsegda, poka ne kontshilos. Poslednee sovetskoe pokolenie. Moskva: Novoe Literaturnoe Obozrenie.

Zhurzhenko, Tatjana 2011: Geopolitika pamjati: pereotsenka itogov Vtoroi mirovoi voiny i borba za gegemoniju v Baltijsko-Tshernomorskom regione. Perekrestki N 3-4/2011: 134-157.

Zvereva, Vera 2004: Istoriya na TV: konstruirovanie proshlogo - Otechestvennye zapiski, 2004(5). [online]. < http://magazines.russ.ru/oz/2004/5/2004 514. $\underline{\text { html }}>[15.9 .2014$.

Filosofian tohtori Olga Davydova-Minguet on yliopistotutkija Itä-Suomen yliopiston Karjalan tutkimuslaitoksessa. 
Olga Davydova-Minguet: Voitonpäivänjuhla Sortavalassa

[http://www.elore.fi/arkisto/2_15/davydova-minguet.pdf]
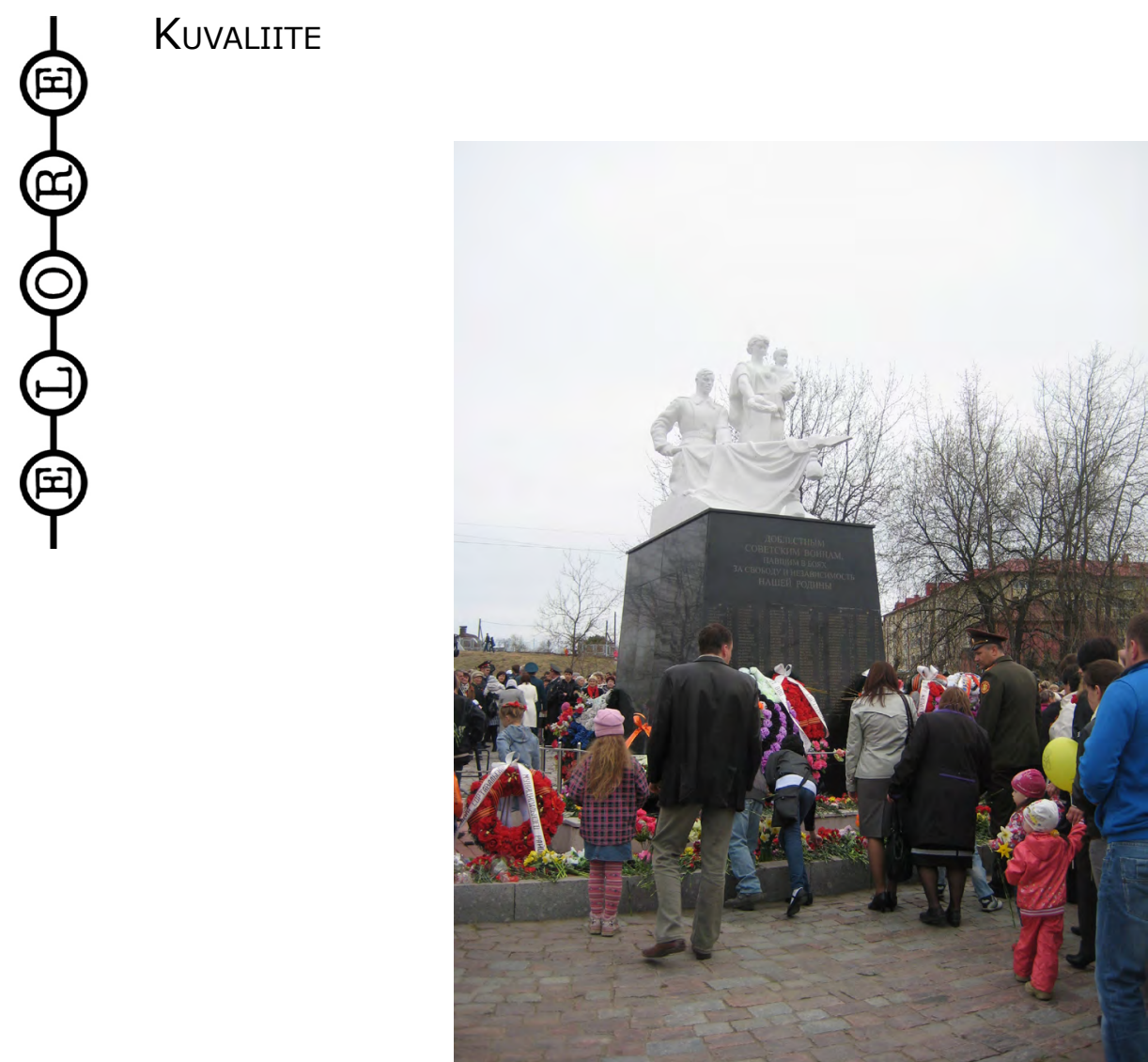

Kuva 1: Muistopatsas neuvostosotilaiden sankarihaudalla. PALAA

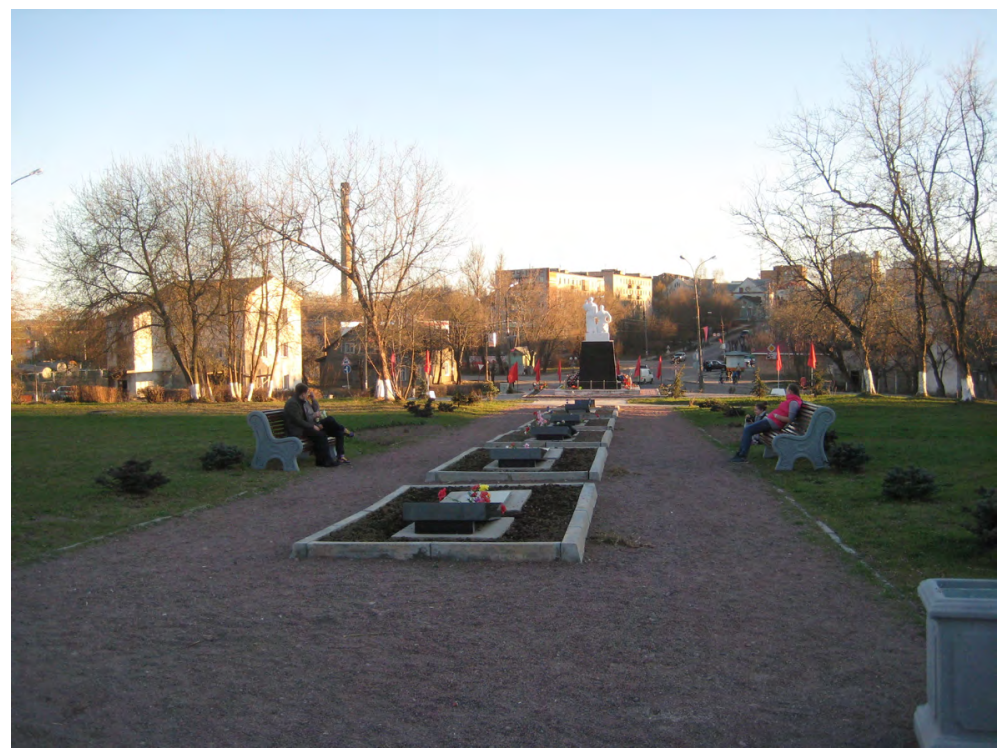

Kuva 2. Muistokuja patsaan takana. PALAA 
Olga Davydova-Minguet: Voitonpäivänjuhla Sortavalassa

[http://www.elore.fi/arkisto/2_15/davydova-minguet.pdf]
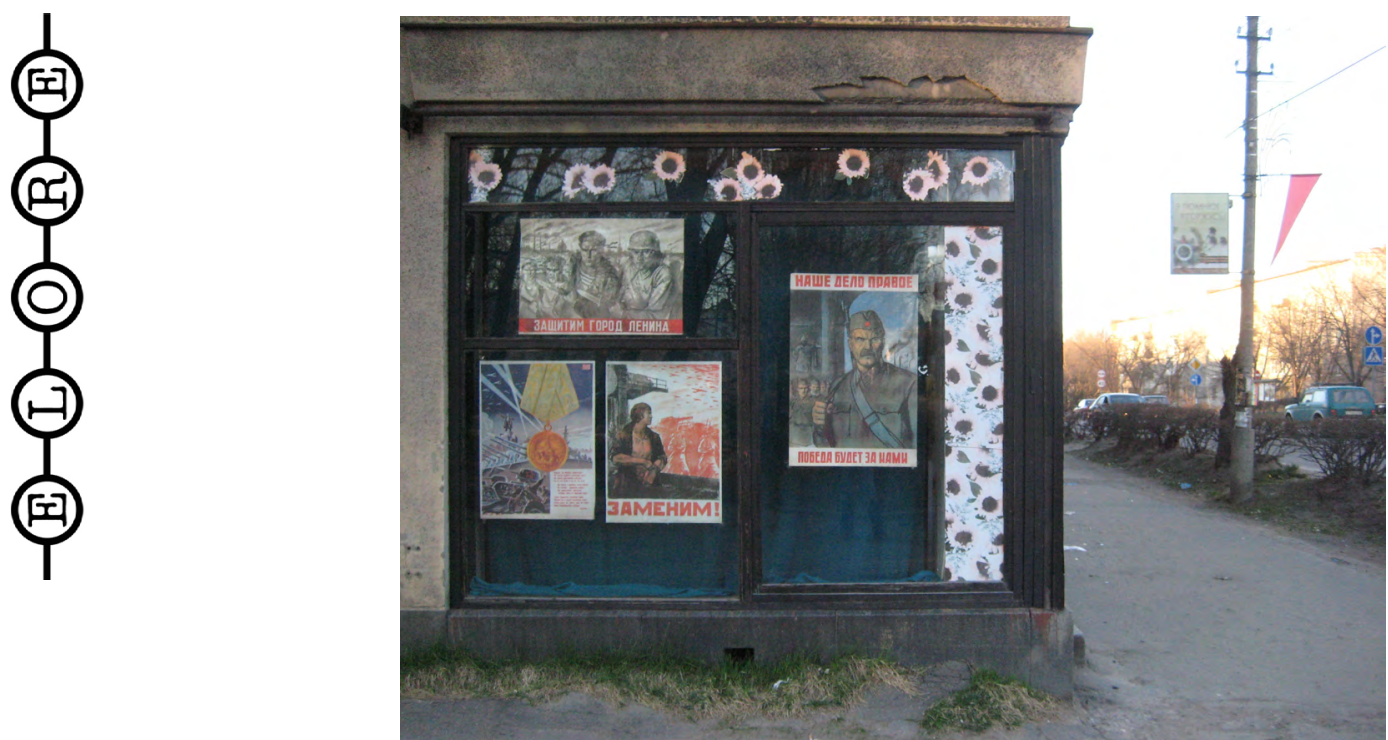

Kuva 3. Kaupungin koristelua. PALAA

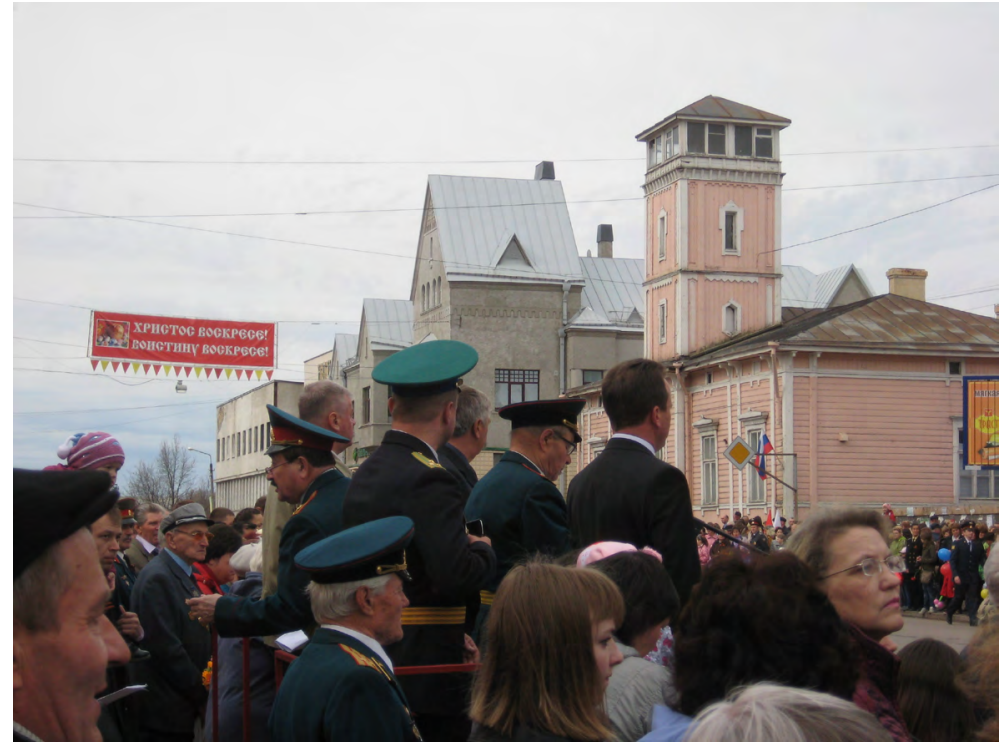

Kuva 4. Viralliset puheet joukkokokouksessa. PALAA

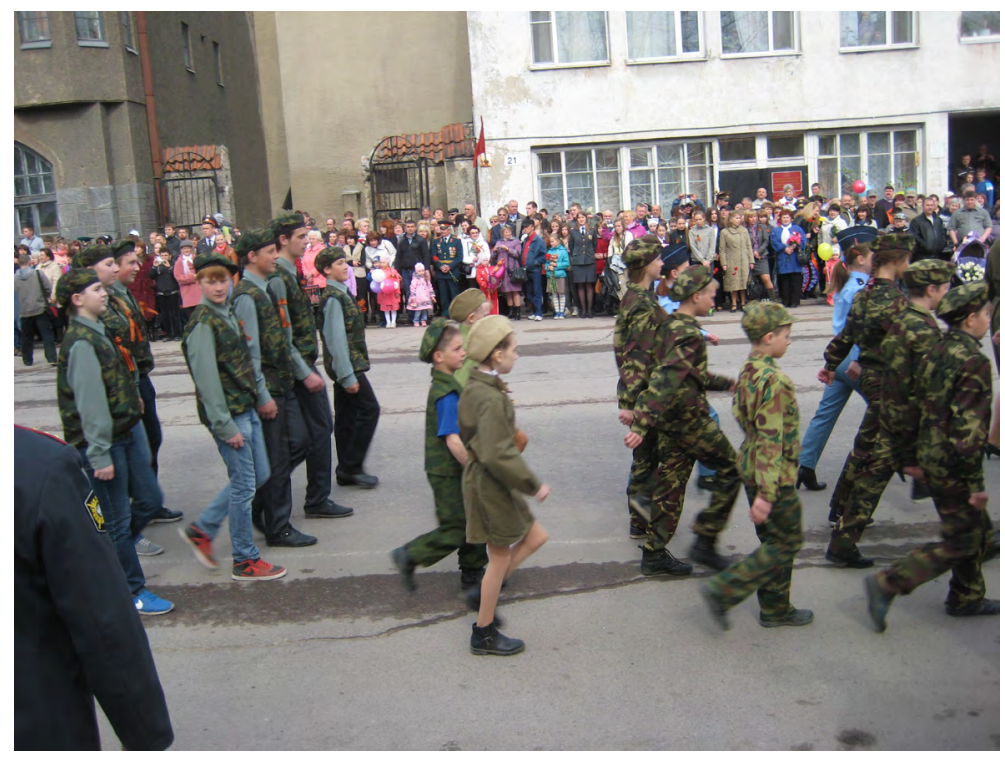

Kuva 5. Lapsiosastoja paraatissa. PALAA 
Olga Davydova-Minguet: Voitonpäivänjuhla Sortavalassa

[http://www.elore.fi/arkisto/2_15/davydova-minguet.pdf]

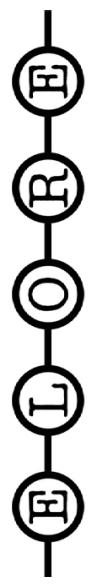

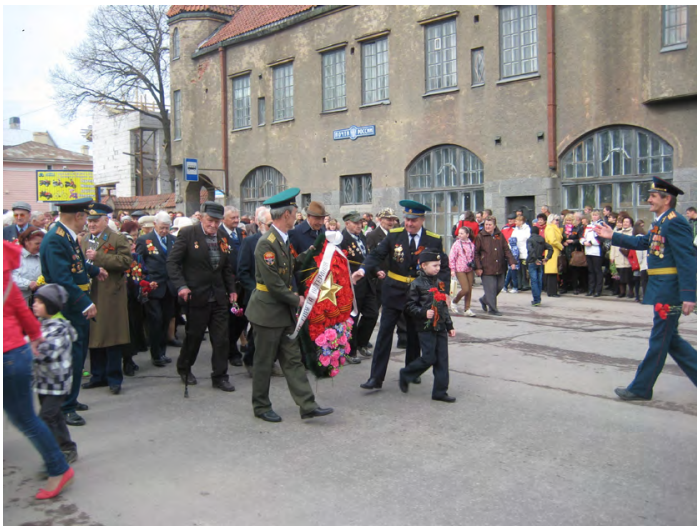

Kuva 6. Veteraaneja ohjataan kolonnaan. PALAA

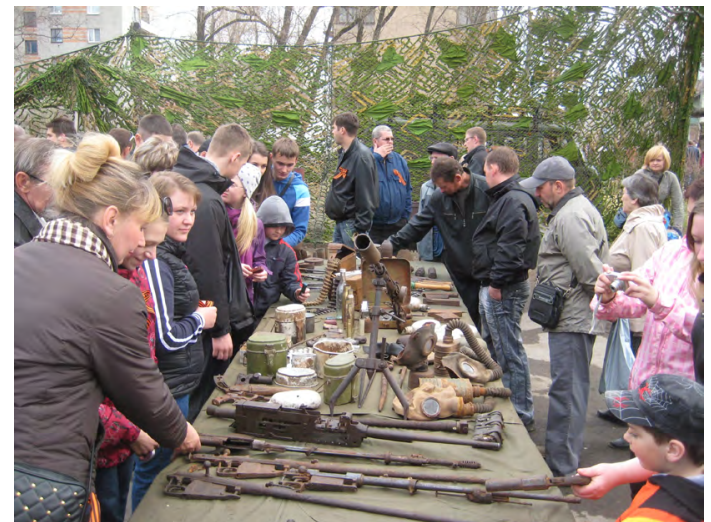

Kuva 7. Etsintäpartion pöytä Agitbrigadassa. PALAA

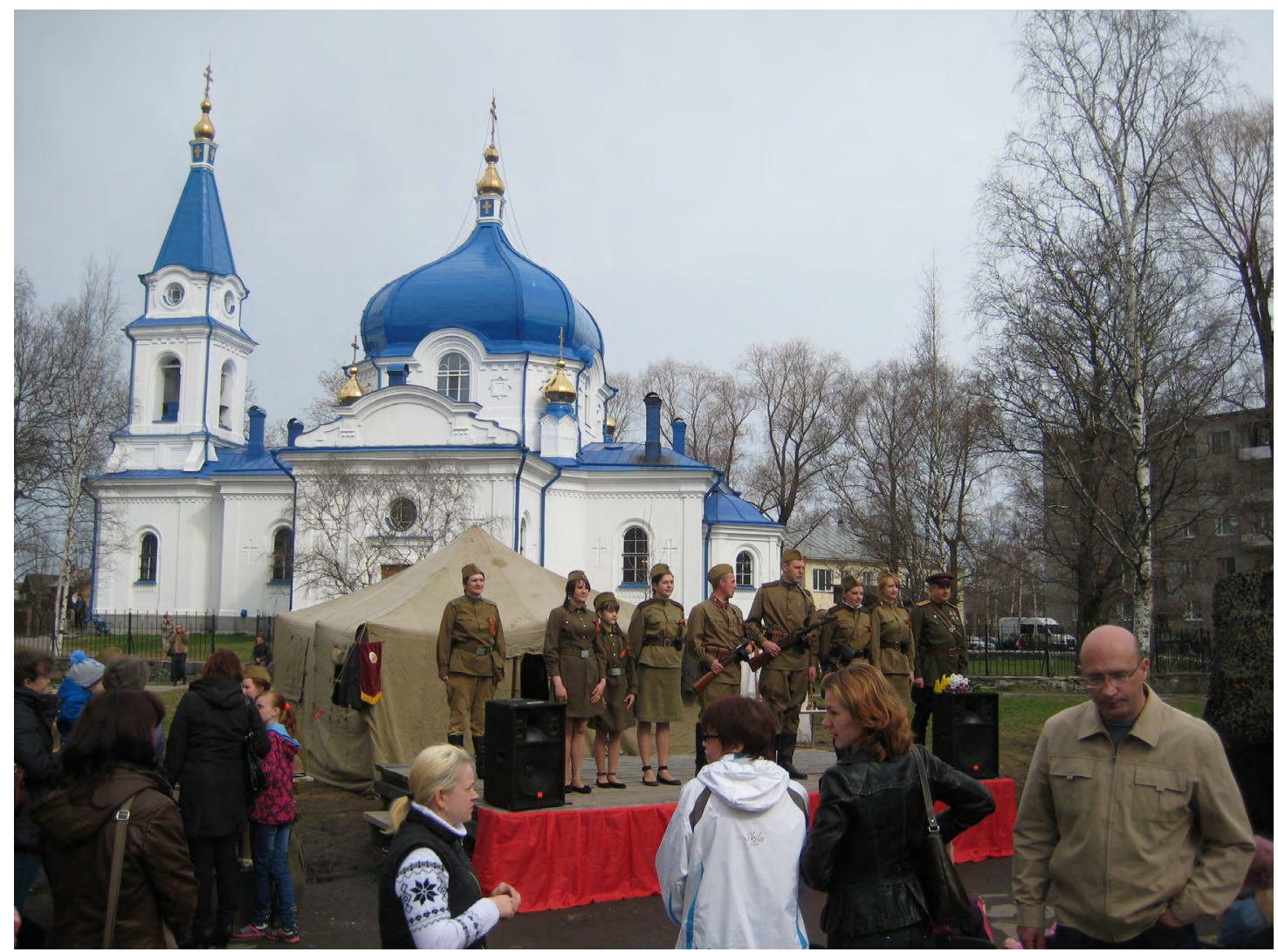

Kuva 8. Agitbrigadan konsertti.

PALAA 
Olga Davydova-Minguet: Voitonpäivänjuhla Sortavalassa

[http://www.elore.fi/arkisto/2_15/davydova-minguet.pdf]
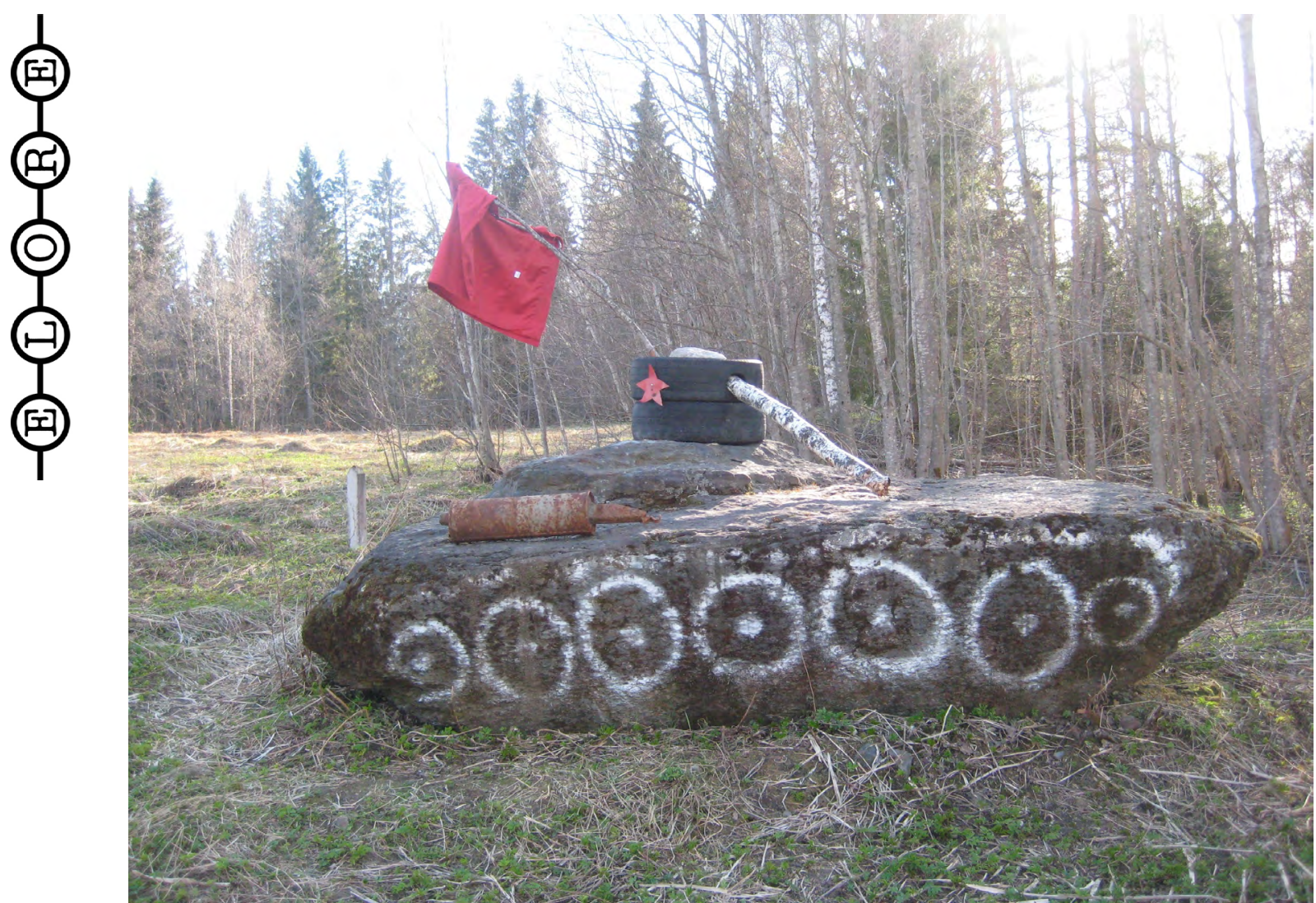

Kuva 9. Itse tehty muistomerkki Ruskealan kylässä.

PALAA

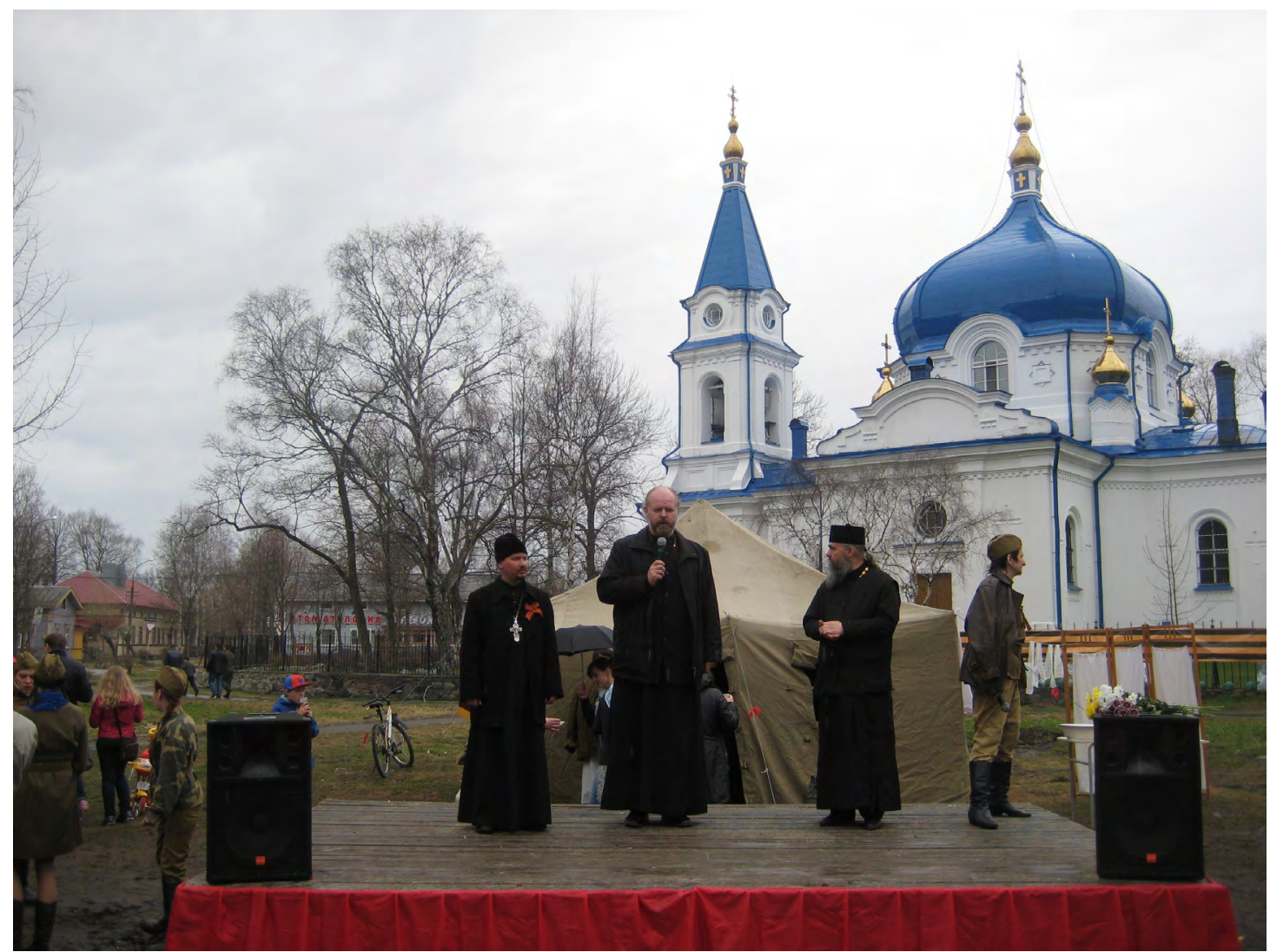

Kuva 10. Pappeja Agitbrigadan lavalla.

PALAA 